\title{
\#USGS
}

Prepared in cooperation with the National Park Service

\section{Hydrologic and Hydraulic Analyses of Great Meadow Wetland, Acadia National Park, Maine}

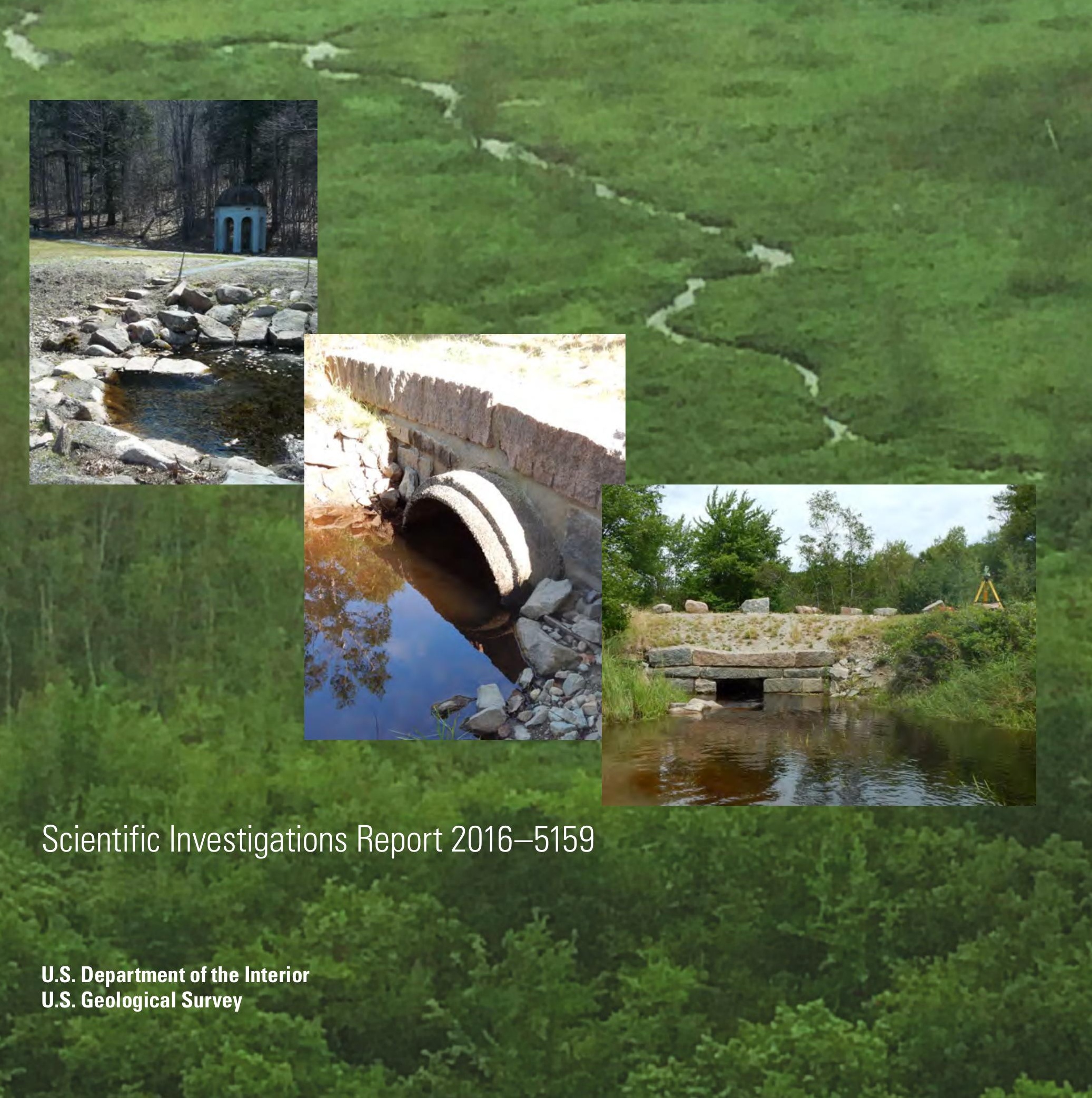




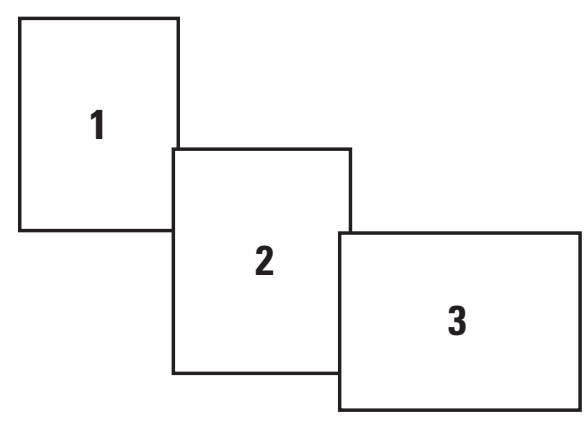

Cover. Great Meadows at Acadia National Park, Maine, October 29, 2015 (Photograph by Brian Henkel, Wild Acadia Project Coordinator).

1. Sieur de Monts Spring House at Acadia National Park, Maine, June 5, 2014

(Photograph by Terrence Talbot, U.S. Geological Survey).

2. Loop Road Culvert at downstream end of Great Meadows at Acadia National Park, Maine, July 17, 2014 (Photograph by Terrence Talbot, U.S. Geological Survey).

3. Loop Road Culvert at downstream end of Great Meadows at Acadia National Park, Maine, July 30, 2014 (Photograph by Terrence Talbot, U.S. Geological Survey). 


\section{Hydrologic and Hydraulic Analyses of Great Meadow Wetland, Acadia National Park, Maine}

By Pamela J. Lombard

Prepared in cooperation with the National Park Service

Scientific Investigations Report 2016-5159 


\section{U.S. Department of the Interior SALLY JEWELL, Secretary}

\section{U.S. Geological Survey Suzette M. Kimball, Director}

\section{U.S. Geological Survey, Reston, Virginia: 2017}

For more information on the USGS - the Federal source for science about the Earth, its natural and living resources, natural hazards, and the environment-visit http://www.usgs.gov or call 1-888-ASK-USGS.

For an overview of USGS information products, including maps, imagery, and publications, visit http://store.usgs.gov.

Any use of trade, firm, or product names is for descriptive purposes only and does not imply endorsement by the U.S. Government.

Although this information product, for the most part, is in the public domain, it also may contain copyrighted materials as noted in the text. Permission to reproduce copyrighted items must be secured from the copyright owner.

Suggested citation:

Lombard, P.J., 2017, Hydrologic and hydraulic analyses of Great Meadow wetland, Acadia National Park, Maine: U.S. Geological Survey Scientific Investigations Report 2016-5159, 39 p., https://doi.org/10.3133/sir20165159.

ISSN 2328-0328 (online) 


\section{Acknowledgments}

I wish to thank Bill Gawley and Bruce Connery of Acadia National Park for sharing their extensive knowledge of the Cromwell Brook watershed; Brian Henkel, the Wild Acadia Project Coordinator for sharing his photos and observations from rainstorms in the watershed; and David Perconti, Course Superintendent at Kebo Valley Golf Club, for granting access and providing invaluable information on beaver activity and historic floods within the study watershed.

Finally, I would like to thank Terrence Talbot, Jeffrey Kinsey, and Sean Andrews of the U.S. Geological Survey for their work collecting field data, and Luke Sturtevant of the U.S. Geological Survey for assistance in geographic information system work and map preparation. 



\section{Contents}

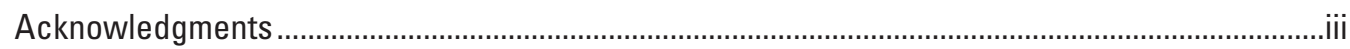

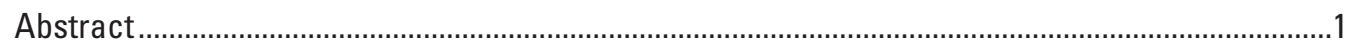

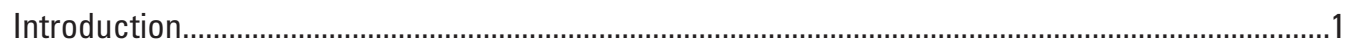

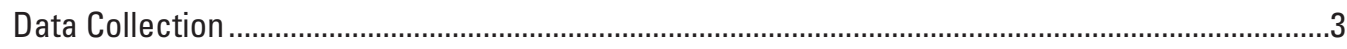

Survey of Elevation Reference Marks, Hydraulic Structures, Underwater Points, and Ground Control Points ....................................................................................................

Light Detection and Ranging Data .....................................................................................

Light Detection and Ranging Data Quality Control and Adjustment .........................................6

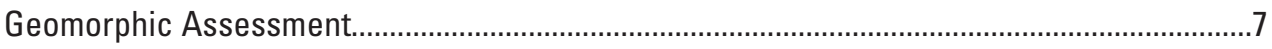

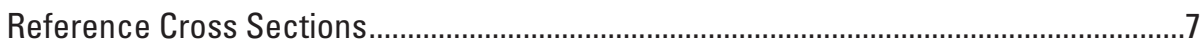

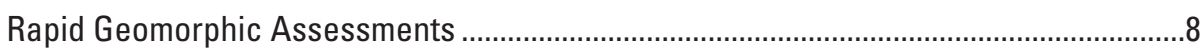

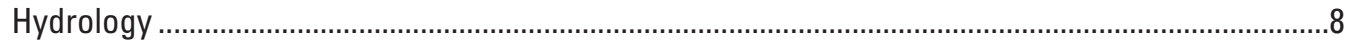

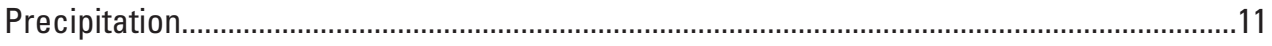

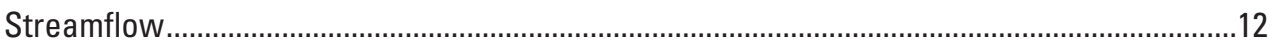

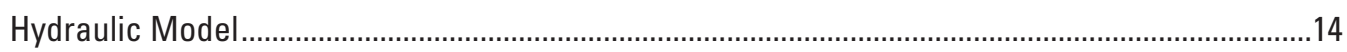

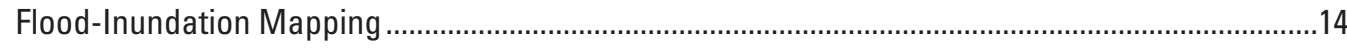

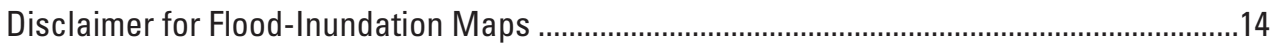

Uncertainties and Limitations Regarding Use of Flood-Inundation Maps ............................14

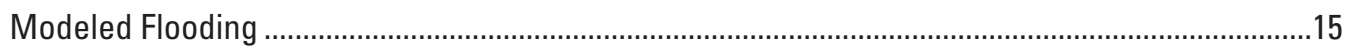

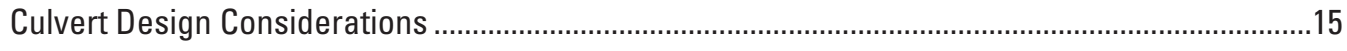

Park Loop Road Culvert Size Scenario Testing ...................................................................15

Effects on Great Meadow Wetland Hydrology from Culvert Replacement .....................16

Effects on Downstream Flooding from Culvert Replacement ...........................................18

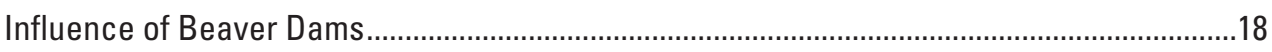

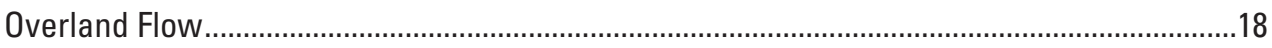

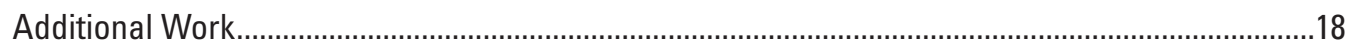

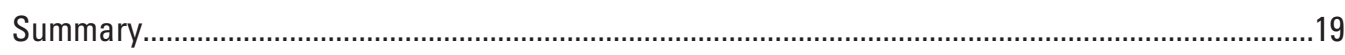

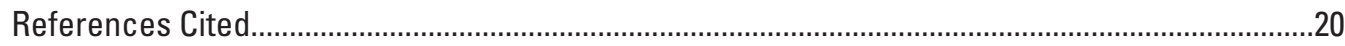

\section{Figures}

1. Map showing the Great Meadow wetland study area, Mount Desert Island, Maine ......2

2. Maps showing location of reference cross sections and elevation reference marks on Cromwell Brook, Mount Desert Island, Maine ...................................................

3. Photographs showing examples of markers for elevation reference marks,

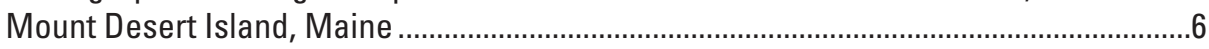

4. Comparison of cross sections surveyed in 2015 versus 2016 on Cromwell Brook...........9

5. Photograph showing the upstream end of the Park Loop Road culvert after 3.28 inches of rainfall at the McFarland Hill rain gage on October 29, 2015, Mount Desert Island, Maine

6. Photograph showing the Sieur de Monts Nature Center parking lot after 3.28 inches of rainfall on October 29, 2015, Mount Desert Island, Maine. 
7. Photograph showing the Sieur de Monts tributary at the Sieur de Monts Nature Center after 3.28 inches of rainfall on October 29, 2015, Mount Desert Island, Maine

8. Modeled water-surface profiles for the 95th percentile April streamflow

9. Modeled water-surface profiles for the peak streamflow with a 2-year recurrence interval.

10. Modeled water-surface profiles for the peak streamflow with a 5-year recurrence interval.

11. Modeled water-surface profiles for the peak streamflow with a 10-year recurrence interval.

12. Modeled water-surface profiles for the peak streamflow with a 25-year recurrence interval.

13. Modeled water-surface profiles for the peak streamflow with a 50-year recurrence interval.

14. Modeled water-surface profiles for the peak streamflow with a 100-year recurrence interval..

15. Flood-inundation map for Cromwell Brook at the Great Meadow Wetland for a flow with a 2-year recurrence interval, Mount Desert Island, Maine. . .31

16. Flood-inundation map for Cromwell Brook at the Great Meadow Wetland for a flow with a 5-year recurrence interval, Mount Desert Island, Maine.

17. Flood-inundation map for Cromwell Brook at the Great Meadow Wetland for a flow with a 10-year recurrence interval, Mount Desert Island, Maine 33

18. Flood-inundation map for Cromwell Brook at the Great Meadow Wetland for a flow with a 25-year recurrence interval, Mount Desert Island, Maine

19. Flood-inundation map for Cromwell Brook at the Great Meadow Wetland for a flow with a 50-year recurrence interval, Mount Desert Island, Maine

20. Flood-inundation map for Cromwell Brook at the Great Meadow Wetland for a flow with a 100 -year recurrence interval, Mount Desert Island, Maine. .36

21. Map showing contour elevations around the Sieur de Monts Nature Center, Mount Desert Island, Maine.

22. Flood-inundation map for Cromwell Brook at the Great Meadow wetland for the peak streamflow with a 10 -year recurrence interval comparing the flooding resulting from a $3.3-\mathrm{ft}$ culvert versus a $10-\mathrm{ft}$ culvert at the Park Loop Road, Mount Desert Island, Maine.

23. Flood-inundation map for Cromwell Brook at the Great Meadow wetland for the peak streamflow with a 25 -year recurrence interval comparing the flooding resulting from a 3.3-ft culvert versus a 10-ft culvert at the Park Loop Road, Mount Desert Island, Maine.

24. Flood-inundation map for Cromwell Brook at the Great Meadow wetland for the peak streamflow with a 100 -year recurrence interval comparing the flooding resulting from a 3.3-ft culvert versus a 10-ft culvert at the Park Loop Road, Mount Desert Island, Maine.

25. Photographs showing the culvert drainage area upstream from the Sieur de Monts Nature Center after 3.28 inches of rainfall on October 29, 2015, Mount Desert Island, Maine. 


\section{Tables}

1. Location, elevation, and description for elevation reference marks surveyed with high precision global positioning system receivers along Cromwell Brook in Acadia National Park, Mount Desert Island, Maine ......................................................................

2. Location and description of reference cross sections on Cromwell Brook in Acadia National Park, Mount Desert Island, Maine ......................................................................7

3. Description of stability index values for rapid geomorphic assessments .......................10

4. Summary of rapid geomorphic assessments on Cromwell Brook and Sieur de Monts tributary by reach in Acadia National Park, Mount Desert Island, Maine.

5. Streamflows for Cromwell Brook from the outflow of the Tarn to the confluence with Kebo Brook and for the mouth of the Sieur de Monts tributary, Mount Desert Island, Maine

6. Flood elevations at the Sieur de Monts Nature Center for increasing culvert sizes at the Park Loop Road, Mount Desert Island, Maine

7. Flood elevations for the Sieur de Monts tributary just upstream from the Great Meadow wetland for increasing culvert sizes at the Park Loop Road, Mount Desert Island, Maine.

8. Flood elevations for Cromwell Brook just upstream from the Park Loop Road for increasing culvert sizes at Park Loop Road, Mount Desert Island, Maine...

\section{Conversion Factors}

[U.S. customary units to International System of Units]

\begin{tabular}{|c|c|c|}
\hline Multiply & By & To obtain \\
\hline \multicolumn{3}{|c|}{ Length } \\
\hline inch (in.) & 2.54 & centimeter $(\mathrm{cm})$ \\
\hline foot $(\mathrm{ft})$ & 0.3048 & meter (m) \\
\hline mile (mi) & 1.609 & kilometer $(\mathrm{km})$ \\
\hline \multicolumn{3}{|c|}{ Area } \\
\hline acre & 4,047 & square meter $\left(\mathrm{m}^{2}\right)$ \\
\hline acre & 0.004047 & square kilometer $\left(\mathrm{km}^{2}\right)$ \\
\hline square mile $\left(\mathrm{mi}^{2}\right)$ & 259.0 & hectare (ha) \\
\hline square mile $\left(\mathrm{mi}^{2}\right)$ & 2.590 & square kilometer $\left(\mathrm{km}^{2}\right)$ \\
\hline
\end{tabular}

Temperature in degrees Celsius $\left({ }^{\circ} \mathrm{C}\right)$ may be converted to degrees Fahrenheit $\left({ }^{\circ} \mathrm{F}\right)$ as ${ }^{\circ} \mathrm{F}=\left(1.8 \times{ }^{\circ} \mathrm{C}\right)+32$.

Temperature in degrees Fahrenheit $\left({ }^{\circ} \mathrm{F}\right)$ may be converted to degrees Celsius $\left({ }^{\circ} \mathrm{C}\right)$ as ${ }^{\circ} \mathrm{C}=\left({ }^{\circ} \mathrm{F}-32\right) / 1.8$. 


\section{Datum}

Vertical coordinate information is referenced to the North American Vertical Datum of 1988 (NAVD 88).

Horizontal coordinate information is referenced to North American Datum of 1983 (NAD 83).

\section{Abbreviations}

$\begin{array}{ll}\text { DEM } & \text { digital elevation model } \\ \text { ERM } & \text { elevation reference mark } \\ \text { GCP } & \text { ground control point } \\ \text { GIS } & \text { Geographic Information System } \\ \text { HEC-RAS } & \text { Hydrologic Engineering Center's River Analysis System } \\ \text { lidar } & \text { light detection and ranging } \\ n \text {-value } & \text { Manning's roughness coefficient } \\ \text { RGA } & \text { rapid geomorphic assessment } \\ \text { RMSE } & \text { root mean square error } \\ \text { USGS } & \text { U.S. Geological Survey }\end{array}$




\title{
Hydrologic and Hydraulic Analyses of the Great Meadow Wetland, Acadia National Park, Maine
}

\author{
By Pamela J. Lombard
}

\section{Abstract}

The U.S. Geological Survey completed hydrologic and hydraulic analyses of Cromwell Brook and the Sieur de Monts tributary in Acadia National Park, Maine, to better understand causes of flooding in complex hydrologic and hydraulic environments, like those in the Great Meadow wetland and Sieur de Monts Spring area. Regional regression equations were used to compute peak flows with from 2 to 100-year recurrence intervals at seven locations. Light detection and ranging data were adjusted for bias caused by dense vegetation in the Great Meadow wetland; and then combined with local ground surveys used to define the underwater topography and hydraulic structures in the study area. Hydraulic modeling was used to evaluate flood response in the study area to a variety of hydrologic and hydraulic scenarios.

Hydraulic modeling indicates that enlarging the culvert at Park Loop Road could help mitigate flooding near the Sieur de Monts Nature Center that is caused by streamflows with large recurrence intervals; however, hydraulic modeling also indicates that the Park Loop Road culvert does not aggravate flooding near the Nature Center caused by the more frequent high intensity rainstorms. That flooding is likely associated with overland flow resulting from (1) quick runoff from the steep Dorr Mountain hitting the lower gradient Great Meadow wetland area and (2) poor drainage aggravated by beaver dams holding water in the wetland.

Rapid geomorphic assessment data collected in June 2015 and again in April 2016 indicate that Cromwell Brook has evidence of aggradation, degradation, and channel widening throughout the drainage basin. Two of five reference cross sections developed for this report also indicate channel aggradation.

\section{Introduction}

Cromwell Brook, and the Great Meadow wetland through which it flows, is a significant ecological, historical, and cultural location at Acadia National Park, Maine (fig. 1). Cromwell Brook flows from the Tarn and is joined by the Sieur de Monts tributary in the Great Meadow wetland. The Sieur de
Monts tributary flows from the historic Sieur de Monts Spring. A number of other smaller tributaries flow into Cromwell Brook upstream and through the Great Meadow wetland.

The Tarn is a manmade impoundment, formed by a small earthen dam. Since its construction, natural aggradation of the pond caused by deposition of sediment into the pond carried by runoff from the steep adjacent hillslopes and high gradient streams entering the pond has changed much of the impoundment from an open water body to a marsh filled with emergent aquatic vegetation. National Park Service staff have hypothesized that aggradation has accelerated because of increased numbers of rainstorms and erosion from roads (Gary Smillie, National Park Service, written commun., November 24, 2010). The accumulation of sediments in the Tarn can be evaluated by noting changes in bed elevations in the pond upstream from the outlet dam. The difficulty of determining rates of accumulation and erosion of sediments in Cromwell Brook increases as it passes through the Great Meadow wetland.

The 116-acre Great Meadow wetland is one of the most important and largest palustrine wetland complexes in Acadia National Park. The western part of the Great Meadow wetland is dominated by red maple (Acer rubrum) swamps, which are uncommon on Mount Desert Island, and have a diverse understory of shrub and herbaceous species (Lubinski and others, 2003). The central and eastern parts of the Great Meadow wetland provide extensive habitat for beavers and are a mosaic of sweetgale (Myrica gale), mixed shrub fens, tussock sedge meadow, and speckled alder (Alnus incana) shrubland. The wetland has numerous ditches and berms, old roads, and manmade drainage channels, some with substantial bank erosion. Beavers with active beaver dams are also present in the wetland.

Immediately adjacent to the southern end of the wetland is the Sieur de Monts developed area, which is a historic cultural landscape (National Park Service, 2009) significant for its association with development of Acadia National Park and for landscape design. Development of the Sieur de Monts site began in 1909 when George B. Dorr purchased the area. It has seen many land use changes since then. It includes four National Register listed buildings (the Abbe Museum, the Nature Center (also known as the Spring House), the Spring Canopy, and the rustic design restroom facility), as well as several significant historic trails. The site also includes the 


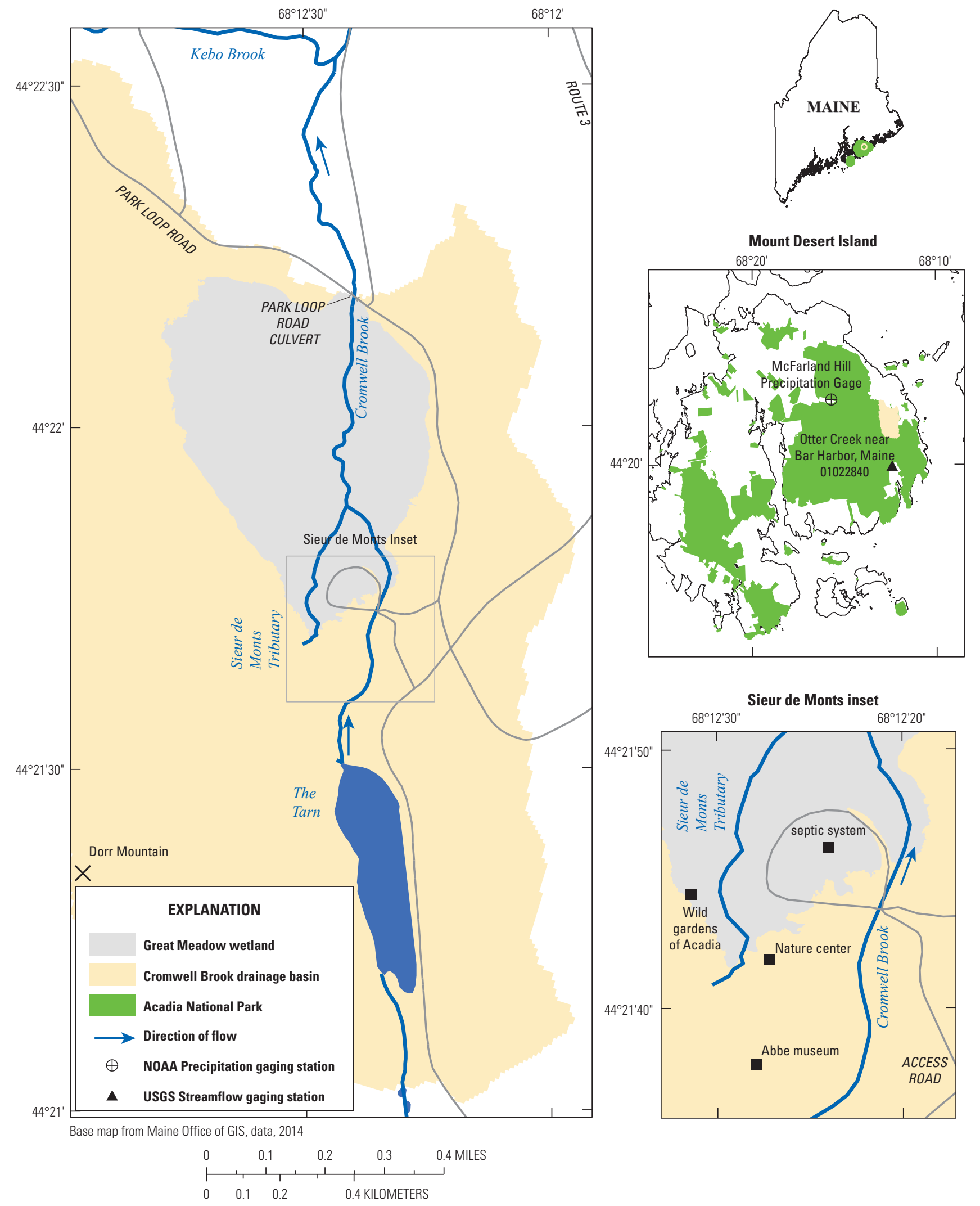

Figure 1. The Great Meadow wetland study area, Mount Desert Island, Maine. 
Wild Gardens of Acadia (a public botanical garden) (fig. 1). At the outlet of the wetland is the National Register listed historic Park Loop Road, the primary road in the park.

Drainage from the Great Meadow wetland exits Acadia National Park by Cromwell Brook through a culvert under the Park Loop Road (see cover photo), compromising the integrity of the culvert and Park Loop Road during periods of high flow. In addition, water floods the Sieur de Monts area at the head of the Great Meadow wetland during large rainstorms. Flooding has inundated the Acadia National Park's botanical gardens at the Wild Gardens of Acadia, caused the closure of the public restroom facilities (that are on a septic system), and damaged the historic buildings at Sieur de Monts.

Acadia National Park staff plan to repair the culvert under the historic Park Loop Road at the outlet of the Great Meadow wetland to mitigate flooding issues; however, they have concerns that without understanding the hydrology and hydraulics of the system, culvert fixes may not solve the flooding problems, could inadvertently dewater the Great Meadow wetland, or flood private homes and municipal property immediately downstream from the Great Meadow wetland. The U.S. Geological Survey (USGS) provides reliable scientific information to describe the interaction of hydrologic systems and assists in understanding their effects on property. In most instances, this involves documenting and analyzing the effects of widely recognized phenomena such as rainfall and runoff processes. On occasion, this involves relatively small-scope studies of watersheds with unique characteristics, such as wetlands with beaver dams and increasing frequency of intense rainfall events that emerge as a flooding hazard. The USGS works within its strategic science direction and with its cooperative partners, such as the National Park Service, to document these emerging hazards and to ensure that scientific methods are applied effectively to better understand these phenomena and thereby minimize loss. The USGS signed an agreement with Acadia National Park in 2014 to complete hydrologic and hydraulic investigations of the Great Meadow wetland.

The purpose of this study is to better understand the hydrologic and hydraulic conditions of the Sieur de Monts area including the Great Meadow wetland during periods of high flow (fig. 1). This report is documentation of work to help the public address the causes of flooding problems in this type of system in the future. One objective is to characterize stormflows on (1) Cromwell Brook from the outlet of the Tarn to the confluence with Kebo Brook and (2) the Sieur de Monts tributary from the Sieur de Monts Spring to Cromwell Brook. Another objective is to model current conditions and test mitigation scenarios with regards to flooding in the area.

\section{Data Collection}

Accurate elevation data are essential to the development of a valid hydraulic model. The availability of light detection and ranging (lidar) data greatly reduces the amount of manually surveyed ground elevation data needed for the model. Although traditional lidar data do not accurately reflect underwater elevations (unless they are bathymetric lidar data) or the elevations of hydraulic structures, lidar can be used to accurately determine elevations of stream banks and flood plains. For this project, USGS staff developed cross sections that combined surveyed data elevations for the underwater points and hydraulic structures with lidar data elevations for the overbanks.

\section{Survey of Elevation Reference Marks, Hydraulic Structures, Underwater Points, and Ground Control Points}

The USGS field technicians established six permanent elevation reference marks (ERMs) in the Cromwell Brook drainage basin using two separate high-precision (millimeter accuracy) dual-frequency Global Positioning System receivers differentially: a Leica GX1220 static base unit and a Topcon Hiper V base and real-time kinematic unit. Three ERMs were established in the Sieur de Monts area and three near the Park Loop Road culvert (table 1; figs. 2 and 3). Technicians submitted Global Positioning System base-receiver data to the National Geodetic Survey for postprocessing using the Online Positioning User Service precise processing service (http://www.ngs.noaa.gov/OPUS/about.jsp). The Online Positioning User Service solved base-point elevations using the network of Continuously Operating Reference Stations (http://www.ngs.noaa.gov/CORS/). Vertical elevations relative to the North American Vertical Datum of 1988 (NAVD 88), horizontal coordinates relative to the North American Datum of 1983 (NAD 83), and detailed location descriptions are provided in table 1.

Technicians surveyed 2 culverts, 3 footbridges, 2 road bridges, 1 weir, and 87 natural cross sections on Cromwell Brook; and 2 culverts, 2 footbridges, and the underwater parts of 23 natural cross sections on the Sieur de Monts tributary. Natural cross sections are spaced 100 to 200 feet apart throughout the Cromwell Brook drainage basin upstream from the confluence with Kebo Brook. Five of these cross sections were designated as reference cross sections that can be revisited to assess future changes in the geomorphology (see the "Geomorphic Assessment" section) (fig. 2); however, any of the cross sections can be resurveyed using their published coordinates for future comparisons. All points were surveyed using a Leica TCR1105 total-station theodolite with infrared laser electronic distance measurement and survey rods with prism-reflectors. Total-station control points were checked and referenced to the ERMs described in table 1.

Technicians surveyed 138 ground control points (GCPs) distributed throughout Great Meadow wetland to evaluate the lidar data. The GCPs include 36 points along the banks of Cromwell Brook as it passes through the Great Meadow wetland in 3 to 4 foot (ft)-tall grass, and 102 points distributed 
Table 1. Location, elevation, and description for elevation reference marks surveyed with high precision global positioning system receivers along Cromwell Brook in Acadia National Park, Mount Desert Island, Maine.

[ERM, elevation reference mark; ID, identification; NAD 83, North American Datum of 1983; ft, foot; NAVD 88, North American Vertical Datum of 1988; `, degree; ', minute; ", second; USGS, U.S. Geological Survey; in., inch]

\begin{tabular}{|c|c|c|c|c|}
\hline \multirow[t]{2}{*}{ ERM ID } & \multicolumn{2}{|c|}{$\begin{array}{l}\text { Coordinates } \\
\text { (NAD 83) }\end{array}$} & \multirow{2}{*}{$\begin{array}{l}\text { Elevation } \\
\text { (ft above the } \\
\text { NAVD 88) }\end{array}$} & \multirow[t]{2}{*}{ Description } \\
\hline & Latitude & Longitude & & \\
\hline 5000 & $44^{\circ} 22^{\prime} 15.5^{\prime \prime}$ & $-068^{\circ} 12^{\prime} 32.1^{\prime \prime}$ & 74.590 & $\begin{array}{l}\text { Rebar pin with Acadia National Park tag and orange rebar cap on the northern } \\
\text { side of Park Loop Road between the road and Great Meadows Loop trail. } \\
979 \mathrm{ft} \text { northwest from the intersection of Great Meadows Drive and Park Loop } \\
\text { Road. } 22 \mathrm{ft} \text { to centerline of Park Loop Road. } 148 \mathrm{ft} \text { east from the wood sign, } \\
\text { "Great Meadows Loop/Hemlock Rd." }\end{array}$ \\
\hline 5001 & $44^{\circ} 22^{\prime} 10.5^{\prime \prime}$ & $-068^{\circ} 12^{\prime} 21.5^{\prime \prime}$ & 67.794 & $\begin{array}{l}\text { Rebar pin with Acadia National Park tag and orange rebar cap in the northeast } \\
\text { corner of the interesection of Great Meadows Drive and Park Loop Road. } 42 \mathrm{ft} \\
\text { from the centerline of Great Meadows Drive. } 21 \mathrm{ft} \text { from the centerline of Park } \\
\text { Loop Road. }\end{array}$ \\
\hline \multicolumn{5}{|r|}{ Sieur de Monts Nature Center } \\
\hline 5003 & $44^{\circ} 21^{\prime} 43.5^{\prime \prime}$ & $-068^{\circ} 12^{\prime} 21.5^{\prime \prime}$ & 69.987 & $\begin{array}{l}\text { Mag nail with metal USGS Survey Marker tag set in the top of the granite wing } \\
\text { wall on the upstream (southern) side box culvert at the entrance to the Sieur de } \\
\text { Monts Nature Center. } 213 \mathrm{ft} \text { northwest from the centerline of hte intersection } \\
\text { (entrance) of Sieur de Monts Road. } 30 \mathrm{ft} \text { from the centerline of Sieur de Monts } \\
\text { Road. }\end{array}$ \\
\hline 5004 & $44^{\circ} 21^{\prime} 44.2^{\prime \prime}$ & $-068^{\circ} 12^{\prime} 21.2^{\prime \prime}$ & 70.109 & $\begin{array}{l}\text { Mag nail with metal USGS Survey Marker tag set in the top of the granite wing } \\
\text { wall on the downstream (northern) side box culvert at the entrance of the Sieur } \\
\text { de Monts Nature Center. } 222 \mathrm{ft} \text { northwest from the centerline of the intersec- } \\
\text { tion of Sieur de Monts Road. } 34 \mathrm{ft} \text { from the centerline of Sieur de Monts Road. }\end{array}$ \\
\hline
\end{tabular}

throughout the wetland primarily along two cross sections that traversed the width of the meadow in grass, alder, or trees.

\section{Light Detection and Ranging Data}

The Acadia National Park lidar data that includes the Cromwell Brook drainage basin are a part of the lidar data for the North East Project, funded in large part by the American Recovery and Reinvestment Act of 2009 (National Oceanic and Atmospheric Administration, 2010). Lidar data were collected in Fall 2010 through Fall 2011 at a greater than or equal to $6.56-\mathrm{ft}$ ground sample distance in which each pixel corresponds to a 6.56 - by 6.56 -ft square area on the ground.
As a part of this project, lidar data were collected for about 2,893 square miles $\left(\mathrm{mi}^{2}\right)$ of Maine while no snow was on the ground. These lidar data, which include the Great Meadow wetland, are quality level 3 with a root mean square error (RMSE) for nonvegetated areas of less than or equal to 7.9 inches (in.) and 95-percent confidence levels for vegetated areas of less than or equal to $15.4 \mathrm{in}$. (Heidemann, 2014). The RMSE is a metric for evaluating the accuracy of lidar datasets. The RMSE is analogous to the standard deviation of a nonbiased dataset (that is, a dataset that has errors equally distributed above and below zero) such that 68 percent of the data would fall within the range of the RMSE or one standard deviation. 

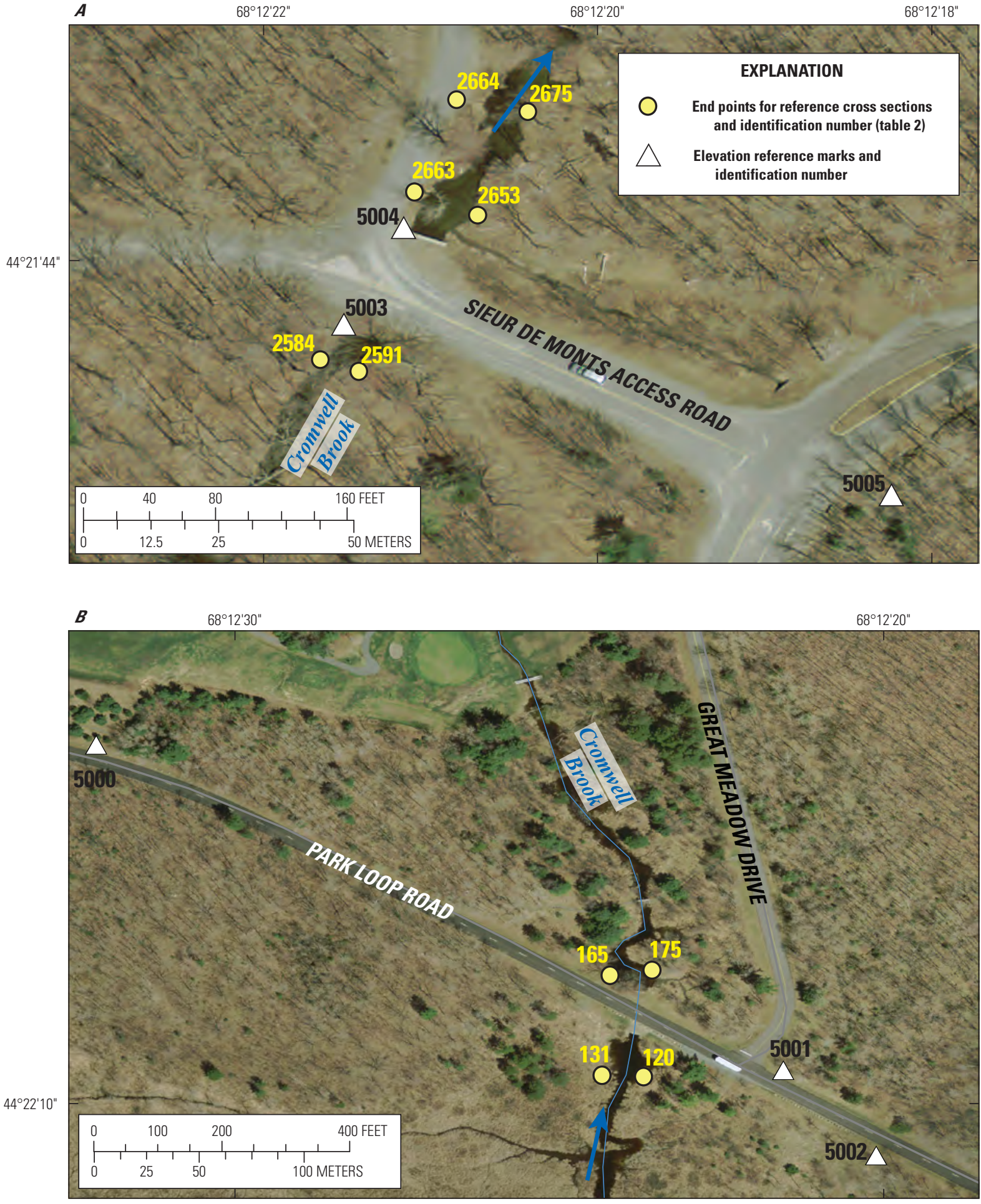

Base map from Maine Office of GIS, data, 2014

North American Datum 1983

Universal Transverse mercator, zone 19

Figure 2. Location of reference cross sections and elevation reference marks on Cromwell Brook, Mount Desert Island, Maine. A, Sieur de Monts Access Road. B, Park Loop Road culvert. 
$\boldsymbol{A}$

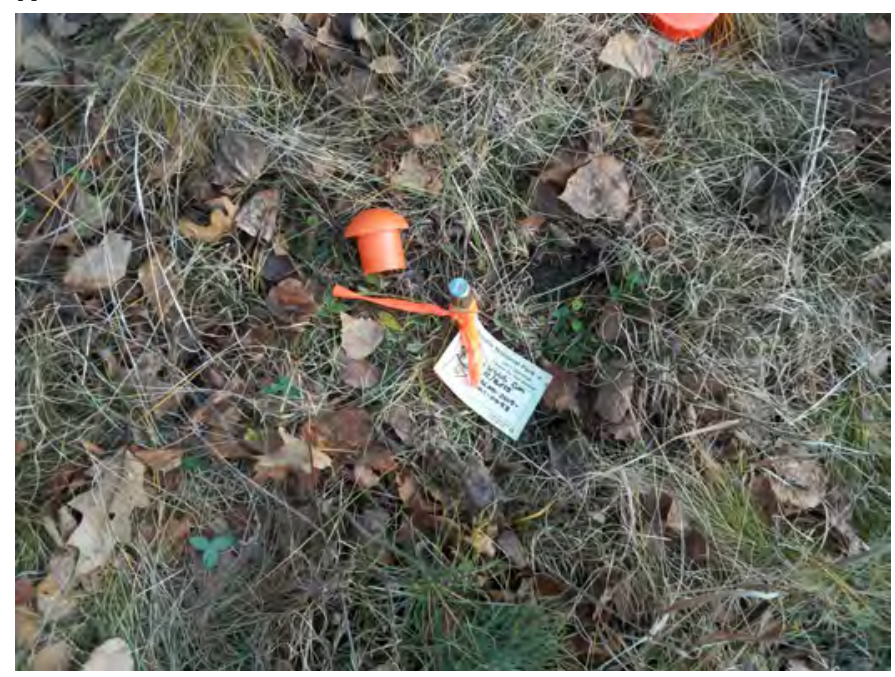

$B$

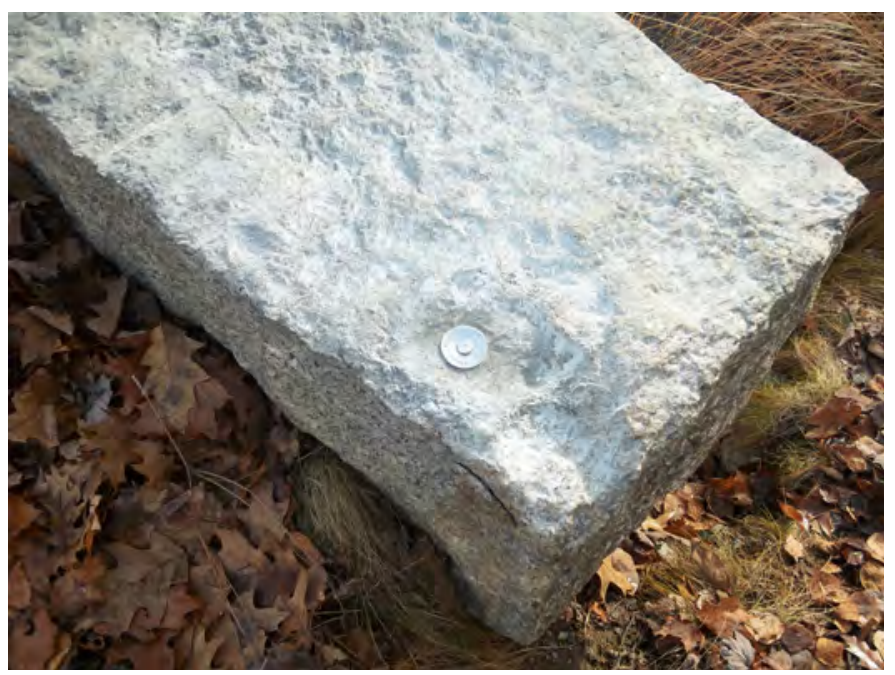

Figure 3. Examples of markers for elevation reference marks, Mount Desert Island, Maine. See table 1 for location descriptions. $A$, elevation reference mark 5001 on Park Loop Road near Great Meadow Loop Trail. B, elevation reference mark 5003 on granite block above Sieur de Monts Access Road culvert.

\section{Light Detection and Ranging Data Quality Control and Adjustment}

Multiple studies have determined that lidar technology does not accurately penetrate thick vegetation in fresh and saltwater marshes and needs to be adjusted to reflect accurate, nonbiased bare-ground elevations that are within the stated accuracy (Toyra and others, 2003; Sadro and others, 2007; Hladik and Alber, 2012). Bowen and Waltermire (2002) documented lidar overestimation of bare-ground elevation in wetlands was most pronounced in areas of dense riparian vegetation with steep bank slopes. Toyra and others (2003) evaluated lidar technology for hydrological applications in wetlands in northeastern Alberta and observed that lidar data did not reflect accurate ground elevations in areas with thick willow cover and dense layers of graminoids (grasses and sedges), even after the bare-ground lidar elevations were adjusted for bias with a block adjustment. The amount of overestimation increased with vegetation height and Leaf Area Index (Toyra and others, 2003); for example, the adjusted lidar ground elevations in graminoid areas were on average $2.7 \mathrm{in.}$ too high and had a RMSE of 6 in. based on 64 points, and the adjusted lidar values in willow-covered areas were on average 6 in. too high and had a RMSE of 10.2 in. based on 22 points (Toyra and others, 2003). In salt marshes surrounding Sapelo Island in Georgia, Hladik and Alber (2102) determined that lidar accuracy was poor because of sensor resolution, instrument errors, and poor laser penetration in dense vegetation. Lidar data bias was particularly apparent in areas surrounding creek banks because of tall vegetation. Uncorrected digital elevation models (DEMs) were not accurate enough to determine elevation changes needed for tidal flood modeling and mapping. Vertical errors of DEMs ranged from 0.1 to $0.82 \mathrm{ft}$ compared to the real-time kinematic ground truth data with the larger offsets for taller vegetation. Overall mean DEM error was reduced from 4 to $-0.4 \mathrm{in}$. and RMSE from 0.5 to $0.3 \mathrm{ft}$ using correction factors based on vegetation type. The investigators recommended that 50 observations for each vegetation class distributed across a study site would be appropriate for developing lidar data correction factors (Hladik and Alber, 2012). National Oceanic and Atmospheric Administration (2012) recommends collecting a minimum of $20 \mathrm{GCPs}$ per land cover category to evaluate lidar data accuracy. This recommended evaluation allows one point to fail the vertical accuracy specification without causing the entire dataset to fail with a 95-percent confidence limit.

The accuracy of the lidar data in Great Meadow was calculated using the 137 GCPs. There is little chance that GCPs will coincide exactly with actual lidar data points; thus, a triangulated irregular network surface was created from the lidar data in order to have a nonbiased method for interpolating a lidar value from the nearest actual data points in order to have a value to compare with the GCPs (National Oceanic and Atmospheric Administration, 2012). Comparisons between the lidar data that covers the Great Meadow and the GCPs collected for this work indicated that lidar data were within the accuracy given for quality level 3 data but had a positive bias as compared to surveyed ground points in Great Meadow. Lidar points inside of the 62-ft contour interval in Great Meadow were on average $0.73 \mathrm{ft}$ higher than their associated GCP and had a RMSE of $0.894 \mathrm{ft}$. The bias diminished outside of the contour elevation of $62 \mathrm{ft}$ (NAVD 88) based on the 11 points surveyed outside of the 62 -ft contour interval. 
For the purposes of this project, the lidar data elevations inside of the $62-\mathrm{ft}$ contour interval were reduced by $0.73 \mathrm{ft}$. After the adjustment, the mean difference between the lidar data and the GCP was $0 \mathrm{ft}$ and the RMSE was $0.519 \mathrm{ft}$ with a 95-percent confidence interval of plus or minus $1.0 \mathrm{ft}$. Many more GCPs around the edge of the meadow and in a variety of different vegetation types would be needed to increase the confidence of any further bias adjustments. These additional data collection and analyses were outside the scope of this project.

\section{Geomorphic Assessment}

Cromwell Brook is predominately straight as it passes through the Great Meadow wetland (fig. 1). Bankfull top widths typically are between 20 and $50 \mathrm{ft}$ except in the wetland where they are as wide as 1,400 ft. The Great Meadow wetland is characterized by intensive historic usage, including roads, trails, berms, and channelized drainage ditches, and it is substantially eroded in some places. To assess the degree to which increased sediment transport and aggrading channels are lowering flow capacity and aggravating flooding in Cromwell Brook through the Great Meadow wetland, USGS technicians set up and surveyed five reference cross sections in the Great Meadow wetland, and completed rapid geomorphic assessments throughout the
Cromwell Brook drainage basin. Because of the short length of this study, each reference cross section was surveyed twice, about 10 to 12 months apart (June 2015 to April 2016). Rapid geomorphic assessments (RGAs) were also completed twice at the same time. See the "Precipitation" section for a description of the hydrologic setting of the period between surveys.

\section{Reference Cross Sections}

Five reference cross sections were established on Cromwell Brook (fig. 1) to assess changes in elevation of the channel with time. Coordinates of the endpoints of the reference cross sections were used to locate and resurvey the cross sections rather than trying to establish permanent stable monuments in Great Meadow. Although using coordinates rather than permanent monuments makes it more challenging to ensure that the cross section is replicated exactly, and some error is introduced by slight changes in location of the points within the cross section, it would be challenging and potentially disruptive to Great Meadow to ensure stable monuments in the wetland. Coordinates of cross section endpoints are included here for future surveys (table 2).

Established cross-section locations include 1 upstream and 2 downstream from the culvert under the Sieur de Monts Access Road (fig. 2A; table 2); and 1 upstream and 1 downstream from the Park Loop Road culvert (fig. 2B; table 2).

Table 2. Location and description of reference cross sections on Cromwell Brook in Acadia National Park, Mount Desert Island, Maine.

[NAD 83, North American Datum of 1983; ft, foot; NAVD 88, North American Vertical Datum of 1988; Bank, the side of the brook when looking downstream; ', degree; ', minute; ", second]

\begin{tabular}{|c|c|c|c|c|}
\hline $\begin{array}{l}\text { Point } \\
\text { identification }\end{array}$ & $\begin{array}{l}\text { Latitude } \\
\text { (NAD 83) }\end{array}$ & $\begin{array}{l}\text { Longitude } \\
\text { (NAD 83) }\end{array}$ & $\begin{array}{c}\text { Elevation } \\
\text { (ft above the NAVD 88) }\end{array}$ & Bank \\
\hline \multicolumn{5}{|c|}{ Cromwell Brook $20 \mathrm{ft}$ upstream from Sieur de Monts Access Road } \\
\hline 2584 & $44^{\circ} 21^{\prime} 43.4009^{\prime \prime}$ & $-068^{\circ} 12^{\prime} 21.6897 "$ & 66.93 & Left Bank. \\
\hline 2591 & $44^{\circ} 21^{\prime} 43.3316^{\prime \prime}$ & $-068^{\circ} 12^{\prime} 21.4588^{\prime \prime}$ & 67.29 & Right Bank. \\
\hline \multicolumn{5}{|c|}{ Cromwell Brook $25 \mathrm{ft}$ downstream from Sieur de Monts Access Road } \\
\hline 2663 & $44^{\circ} 21^{\prime} 44.4074^{\prime \prime}$ & $-068^{\circ} 12^{\prime} 21.1244^{\prime \prime}$ & 68.35 & Left Bank. \\
\hline 2653 & $44^{\circ} 21^{\prime} 44.2683^{\prime \prime}$ & $-068^{\circ} 12^{\prime} 20.7494^{\prime \prime}$ & 66.41 & Right Bank. \\
\hline \multicolumn{5}{|c|}{ Cromwell Brook $83 \mathrm{ft}$ downstream from Sieur de Monts Access Road } \\
\hline 2664 & $44^{\circ} 21^{\prime} 44.9602^{\prime \prime}$ & $-068^{\circ} 12^{\prime} 20.8733^{\prime \prime}$ & 68.64 & Left Bank. \\
\hline 2675 & $44^{\circ} 21^{\prime} 44.8866^{\prime \prime}$ & $-068^{\circ} 12^{\prime} 20.4471^{\prime \prime}$ & 66.60 & Right Bank. \\
\hline \multicolumn{5}{|c|}{ Cromwell Brook $65 \mathrm{ft}$ upstream from Park Loop Road } \\
\hline 131 & $44^{\circ} 22^{\prime} 10.4289^{\prime \prime}$ & $-068^{\circ} 12^{\prime} 24.3632^{\prime \prime}$ & 60.59 & Left Bank. \\
\hline 120 & $44^{\circ} 22^{\prime} 10.4102^{\prime \prime}$ & $-068^{\circ} 12^{\prime} 23.7269^{\prime \prime}$ & 60.41 & Right Bank. \\
\hline \multicolumn{5}{|c|}{ Cromwell Brook $30 \mathrm{ft}$ downstream from Park Loop Road } \\
\hline 165 & $44^{\circ} 22^{\prime} 11.9691^{\prime \prime}$ & $-068^{\circ} 12^{\prime} 24.2426^{\prime \prime}$ & 63.58 & Left Bank. \\
\hline 175 & $44^{\circ} 22^{\prime} 12.0455^{\prime \prime}$ & $-068^{\circ} 12^{\prime} 23.5938^{\prime \prime}$ & 60.89 & Right Bank. \\
\hline
\end{tabular}


Technicians surveyed cross sections at the beginning of the study period in the spring of 2015 and again at the end of the project in the spring of 2016 in order to establish baseline conditions from which geomorphologic changes can be assessed. We looked at changes in cross-section plots, cross-sectional flow area based on the water surface from a theoretical 2-year peak flow output by the Hydrologic Engineering Center's River Analysis System (HEC-RAS), and surveyed channel inverts (the point with the lowest elevation in a cross section) from 2015 to 2016 for each of the locations (fig. 4).

Cross-section plots comparing the 2015 and 2016 surveys of Cromwell Brook $20 \mathrm{ft}$ upstream from the Sieur de Monts Access Road indicate little change in the crosssection elevations. The change in cross-sectional areas for theoretical 2-year peak flows upstream from the Access Road is less than 2 percent, and the channel invert changed by $0.2 \mathrm{ft}$ (fig. $4 A$ ). The cross section $25 \mathrm{ft}$ downstream from the Access Road shows aggradation from 2015 to 2016 (fig. 4B). Cross-sectional flow area for theoretical 2-year peak flow decreased by 25 percent, and the channel invert increased by $0.7 \mathrm{ft}$. Although the cross-sectional area for theoretical 2-year peak flow decreased by 10 percent in the cross section $83 \mathrm{ft}$ downstream from the Access Road, and there may be some aggradation, the channel invert is within $0.2 \mathrm{ft}$ and changes may be due to slightly different points being surveyed (fig. 4C). The cross section $65 \mathrm{ft}$ upstream from Park Loop Road shows a small amount of aggradation. The cross-sectional flow area decreased by 5 percent, and the channel invert increased by $0.8 \mathrm{ft}$ (fig. $4 D$ ). The figure of the cross section downstream from Park Loop Road only includes survey points from 2015 because results of the 2016 survey indicated that changes in the cross section were due to a difference in location rather than a change between years (fig. 4E). Reference cross sections could be surveyed in the future to identify changes with time, and determine if aggradation or degradations in a particular cross section indicates a multi-year trend or is typical of year-to-year variability. If changes in reference cross-section elevations are determined, then cross-section elevations in the hydraulic model would need to be updated before future flooding scenarios are tested.

\section{Rapid Geomorphic Assessments}

In addition to the reference cross sections, USGS field technicians completed RGAs throughout the Cromwell Brook drainage basin. The RGAs were made following methodology adopted by the Maine Department of Environmental Protection from New York State protocols (New York State Department of Environmental Conservation, 2015) in order to identify general patterns of aggradation, degradation, and channel widening in the Sieur de Monts area (fig. 1). The RGAs include identifying if a series of indicators in each category are present or absent. Each RGA also includes a calculated stability index. The stability index is calculated by adding up all the geomorphic indicators that were present and dividing by the total potential number of indicators (34). Descriptions of the interpretation of stability index values are in table 3. Although RGAs are somewhat subjective, and can vary based on water levels and observer biases, they can provide a quick assessment of conditions. The RGAs can be calibrated with the surveyed reference cross sections to determine if reference cross sections are changing throughout the drainage basin.

Technicians completed RGAs within the study area in June 2015 and again in April 2016 to determine if there were changes in the reaches during the year. In 2015, 14 reaches were assessed. In 2016, some of the shorter reaches were combined into nine longer reaches of like morphology. Summaries in table 4 describe the combined reaches. Because the RGA is based on the presence or absence of geomorphic indicators, the RGAs from the shorter 2015 reaches were easily combined for comparison with the 2016 reaches.

Although, in general, water levels were higher in 2015 than in 2016, the presence of a large beaver dam $300 \mathrm{ft}$ upstream from Park Loop Road in 2016 resulted in higher water upstream from it and obscured some of the features observed in 2015. Signs of aggradation, degradation, widening, and planimetric form adjustment were in evidence throughout the drainage basin in 2015 and 2016 (table 4). Most reaches in the Cromwell Brook drainage basin were classified as "being in adjustment" based on the evidence of these geomorphic indicators that resulted in stability indices of 0.4 or greater in most reaches for most years (table 4).

The RGAs are most useful for documenting changes during periods longer than 1 year; thus, the geomorphic data presented in this report should be viewed primarily as providing a baseline for future assessments. Based on the very small sample size and the short period between surveys, we are not able to assess the extent to which the RGAs agree with the changes in the reference cross sections from one year to the next.

\section{Hydrology}

Understanding the hydrology of Cromwell Brook is critical to characterizing the flooding problems within the Great Meadow wetland. Streamflow gages and precipitation gages with long-term (greater than ten year) records would provide data that could be used to estimate floods with from ten to 100-year recurrence intervals, and to evaluate hydrologic characteristics of the watershed such as the time between the center of volume of the rainfall in a storm and the resulting peak streamflow. Because these data are not currently (2016) available in the Cromwell Brook drainage basin, the techniques used to estimate precipitation and streamflows are described below. 

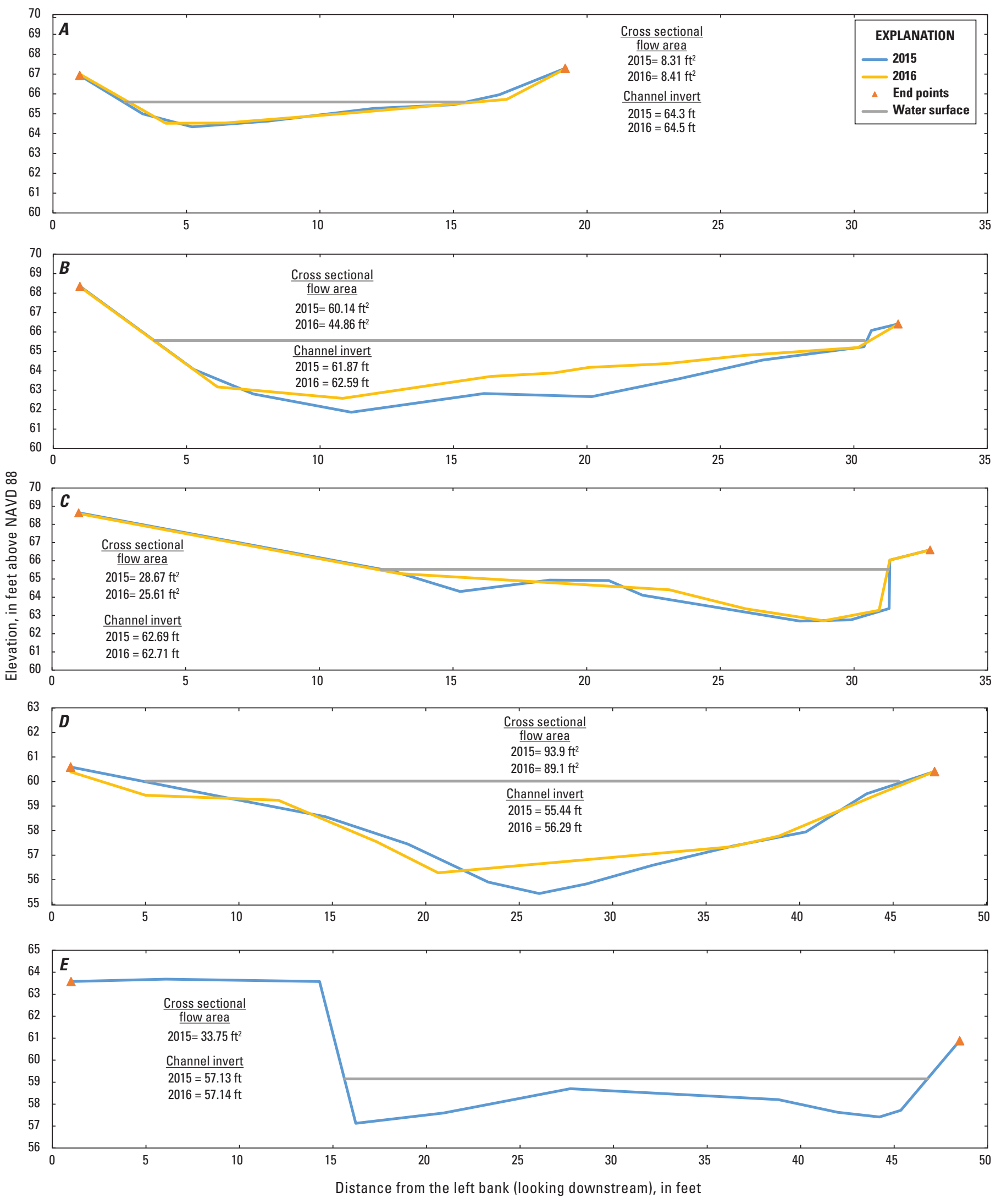

Figure 4. Comparison of cross sections surveyed in 2015 versus 2016 on Cromwell Brook. The water surface represents a theoretical 2-year peak flow, which is used to compute cross-sectional flow area. $A, 20$ feet (ft) upstream from the Sieur de Monts Access Road. $B, 25$ $\mathrm{ft}$ downstream from the Sieur de Monts Access Road. C, $83 \mathrm{ft}$ downstream from the Sieur de Monts Access Road. $D, 65 \mathrm{ft}$ upstream from the Park Loop Road. E, $65 \mathrm{ft}$ downstream from the Park Loop Road. 
Table 3. Description of stability index values for rapid geomorphic assessments.

[SI, stability index value]

\begin{tabular}{lc}
\hline \multicolumn{1}{c}{ SI and class } & \multicolumn{1}{c}{ Description } \\
\hline $\begin{array}{l}\text { Stable } \\
\text { St }<0.25\end{array}$ & $\begin{array}{c}\text { Metrics describing channel form are within the expected range of variance (typically accepted as one standard } \\
\text { deviation from the mean) for stable channels of similar type. }\end{array}$ \\
$0.25<\mathrm{SI}<0.40$ & Metrics are within the expected range of variance as defined above but with evidence of stress. \\
Transitional & \\
$0.40<\mathrm{SI}<1.0$ & Metrics are outside of the expected range of variance for channels of similar type. \\
In adjustment &
\end{tabular}

Table 4. Summary of rapid geomorphic assessments on Cromwell Brook and Sieur de Monts tributary by reach in Acadia National Park, Mount Desert Island, Maine.

\begin{tabular}{|c|c|c|c|c|c|}
\hline Year & $\begin{array}{l}\text { Number of indicators of } \\
\text { aggradation present }\end{array}$ & $\begin{array}{l}\text { Number of indicators of } \\
\text { degradation present }\end{array}$ & $\begin{array}{l}\text { Number of indicators } \\
\text { of widening present }\end{array}$ & $\begin{array}{l}\text { Number of indicators of plani- } \\
\text { metric form adjustment present }\end{array}$ & Stability index value ${ }^{1}$ \\
\hline \multicolumn{6}{|c|}{ Cromwell Brook } \\
\hline 2015 & 4 & 5 & 6 & 3 & 0.52 \\
\hline 2016 & 5 & 5 & 7 & 2 & 0.59 \\
\hline 2016 & 6 & 4 & 6 & 5 & 0.62 \\
\hline \multicolumn{6}{|c|}{ Granite footbridge upstream from Sieur de Monts access Road to Sieur de Monts Access Road culvert } \\
\hline 2015 & 8 & 3 & 8 & 2 & 0.62 \\
\hline 2016 & 6 & 4 & 7 & 1 & 0.53 \\
\hline \multicolumn{6}{|c|}{350 feet downstream from Sieur de Mont Access Road culvert to confluence with Sieur de Monts tributary } \\
\hline 2015 & 2 & 2 & 5 & 1 & 0.29 \\
\hline 2016 & 5 & 4 & 5 & 3 & 0.44 \\
\hline \multicolumn{6}{|c|}{ Confluence with Sieur de Monts tributary to Park Loop Road culvert } \\
\hline 2015 & 5 & 2 & 4 & 4 & 0.44 \\
\hline 2016 & 4 & 2 & 3 & 5 & 0.41 \\
\hline \multicolumn{6}{|c|}{ Park Loop Road culvert to wooden bridge on Great Meadows Loop Trail } \\
\hline 2015 & 5 & 4 & 8 & 4 & 0.62 \\
\hline 2016 & 6 & 4 & 6 & 3 & 0.55 \\
\hline 2015 & 2 & 1 & 1 & 2 & 0.18 \\
\hline 2016 & Reach not accessible & in 2016 & & & \\
\hline
\end{tabular}

\footnotetext{
${ }^{1}$ See table 3 for explanations of the stability index values.
} 


\section{Precipitation}

A rain gage is not currently (2016) in the Cromwell Brook drainage basin. The McFarland Hill rain gage (latitude $44.3738^{\circ}$ and longitude $-68.2591^{\circ}$ ) at Acadia National Park (part of the National Atmospheric Deposition Program) is the closest source of historical rain data. The rain gage is 2.5 miles (mi) northwest of the Cromwell Brook drainage basin on the ridgeline of McFarland Mountain. The rain gage has been in operation from 1982 to the present (2016) at 15-minute intervals.

Rain data at the McFarland Hill rain gage indicate there were rainstorms producing more than $5 \mathrm{in}$. of rain in the fall of 1986 and again in 1987. Rainfall for February 18-19, 1988, totaled 4 in., which was preceded by 1.9 in. on February 12 and followed by $3 \mathrm{in}$. on March 9. This amount of rainfall resulted in more than 1-ft deep flooding inside the Sieur de Monts Nature Center. Multiple large rainstorms in 2005, 2007, and 2008 produced more than 4 in. of rainfall in 24 hours preceded by rainstorms of 1 to $2 \mathrm{in}$. and resulted in flooding around the Sieur de Monts Nature Center. In 2005, two of these rainstorms in the fall produced more than $5 \mathrm{in}$. of rain in 24 hours. Data from the McFarland Hill rain gage indicate that rainfall never exceeded 4 in. on any day in 1981-2005. Rainfall exceeded 4 in. on 4 days in 2005 and 2 days in 2007 and 2008 (National Atmospheric Deposition Program, 2015).

Precipitation frequency curves for Bar Harbor that include data through 1993 (Wilks and Cember, 1993) were recently updated with NOAA's Precipitation Frequency Data Server (http://dipper.nws.noaa.gov/hdsc/pfds/; National Oceanic and Atmospheric Administration, 2015). Updated frequency curves indicate that 1-day rainstorms with from 2 - to 100 -year recurrence intervals have increased from 0.8 to 1 in., respectively. Another way to consider these precipitation frequency curve increases is that a 1-day rainstorm that used to happen on average once every 5 years ( 3.25 in.) now happens on average every 1.5 years (Wilks and Cember, 1993; National Oceanic and Atmospheric Administration, 2015). Although an analysis of the precipitation data at the McFarland Hill rain gage is beyond the scope of this project, current (2015) frequency curves indicate that the rainstorms in 1986, 1987, and 2005 that produced 5 in. of rain (described above) have 10-year recurrence intervals (National Oceanic and Atmospheric Administration, 2015); however, frequency curves from 1993 indicate that these same rainstorms previously would have had a 25 -year recurrence interval (Wilks and Cember, 1993).

Acadia National Park Service staff and the Maine Natural History Observatory have observed and documented overland flooding around the Sieur de Monts Nature Center parking area caused by rainstorms with from 3 to 4 in. of rain in addition to the flooding of the area caused by larger rainstorms. These 3 to 4 in. rainstorms can happen multiple times a year. The period of this study from June 2015 to April 2016 was characterized by a total of 44 in. of rain. The wettest months were June 2015 (7.44 in. of rain) and
February 2016 (6.01 in. of rain). The largest rainstorms produced 2.99, 3.13, and 3.19 in. of rain on June 21, September 30, and October 29, 2015, respectively, at the McFarland Hill rain gage on Mount Desert Island (National Atmospheric Deposition Program, 2015), which filled the Park Loop Road culvert (fig. 5) and resulted in overland flow around the Sieur de Monts Nature Center-including the parking area (figs. 6 and 7) (National Atmospheric Deposition Program, 2015).

On average, rainfall totals 3 in. during a 24-hour period once every year according to current frequency curves (National Oceanic and Atmospheric Administration, 2015); however, 1993 frequency curves indicate that rainfall would have totaled 3 in. once every 2 to 5 years (Wilks and Cember, 1993). Several studies have determined statistically significant increases in the number and intensity of extreme rainstorms in the northeast in the 20th century, with much of the increase during the past three decades (Karl and others, 1996; Groisman and others, 2004).

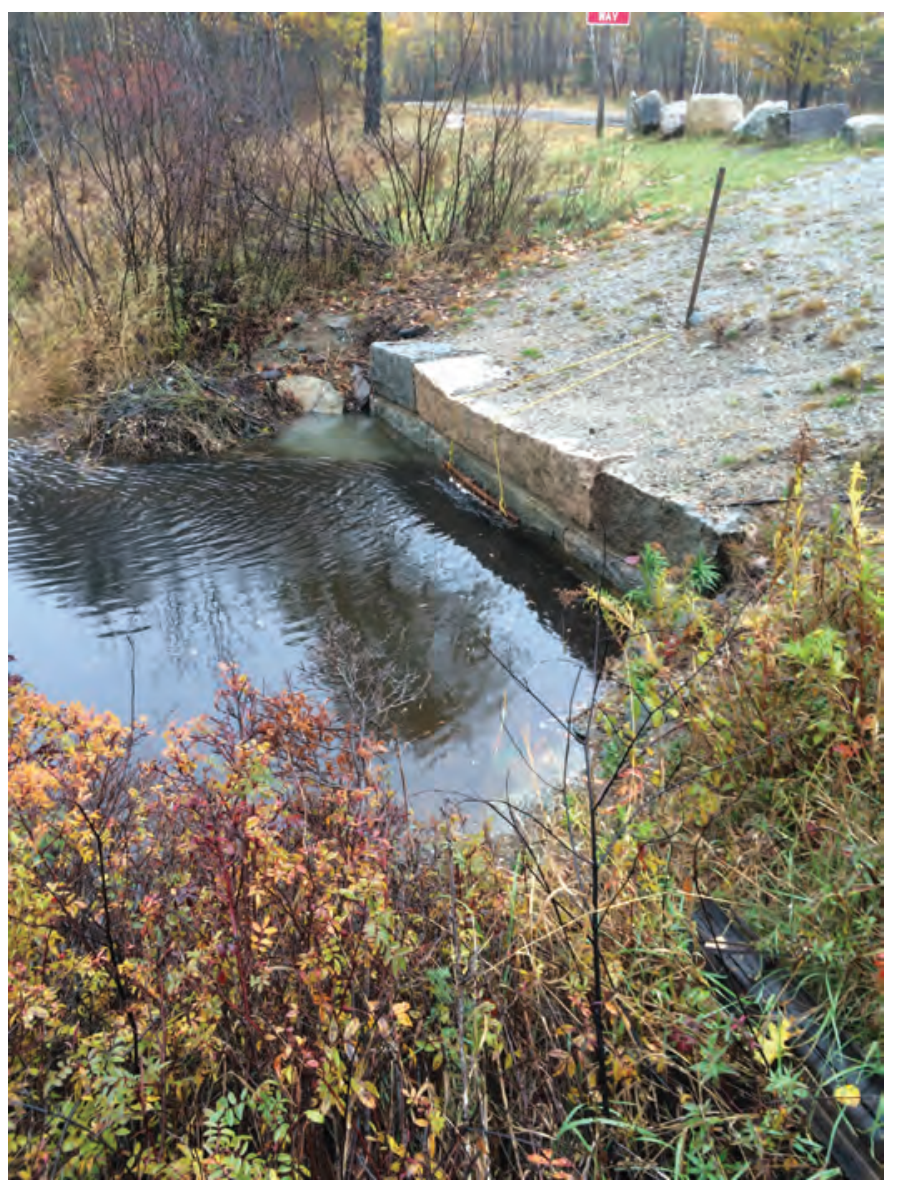

Figure 5. The upstream end of the Park Loop Road culvert (submerged) after 3.28 inches of rainfall at the McFarland Hill rain gage on October 29, 2015, Mount Desert Island, Maine. 


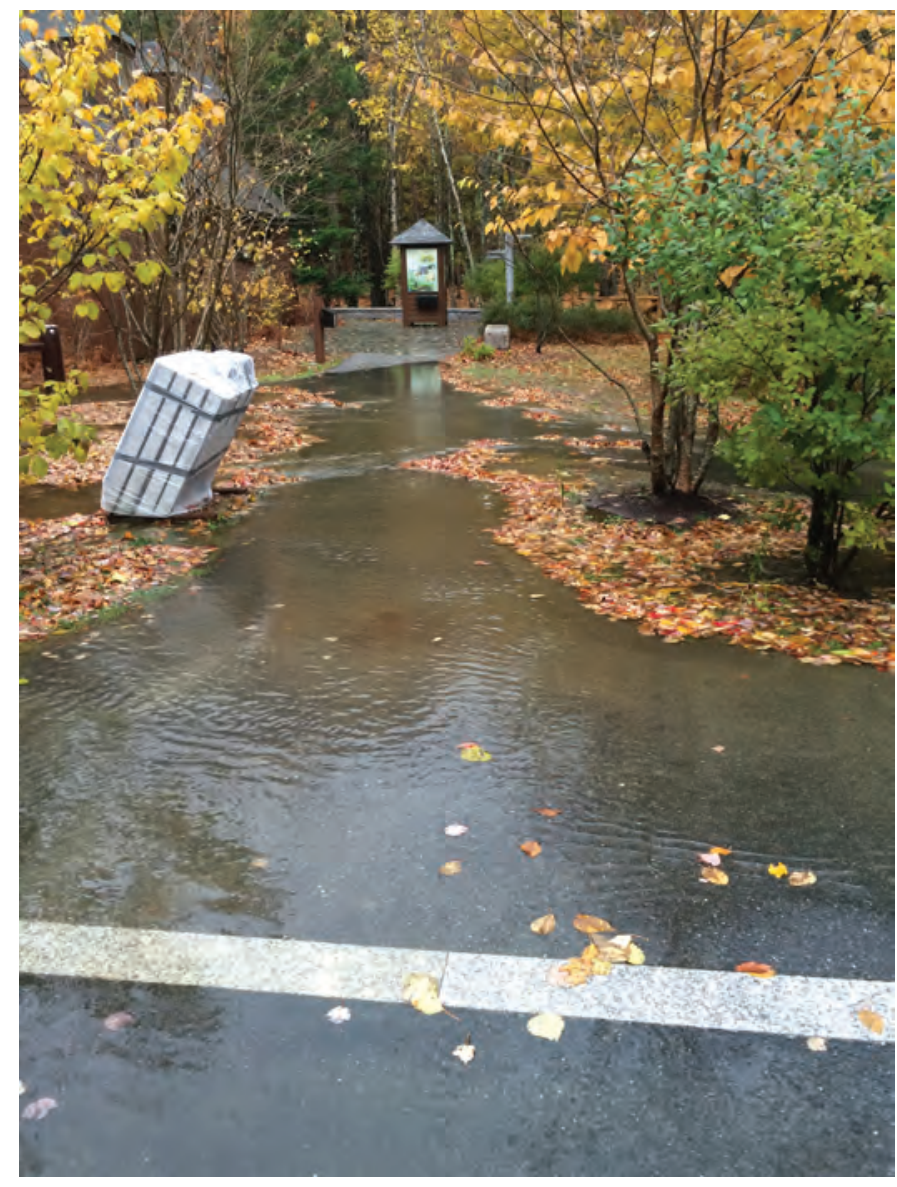

Figure 6. The Sieur de Monts Nature Center parking lot after 3.28 inches of rainfall on October 29, 2015, Mount Desert Island, Maine.

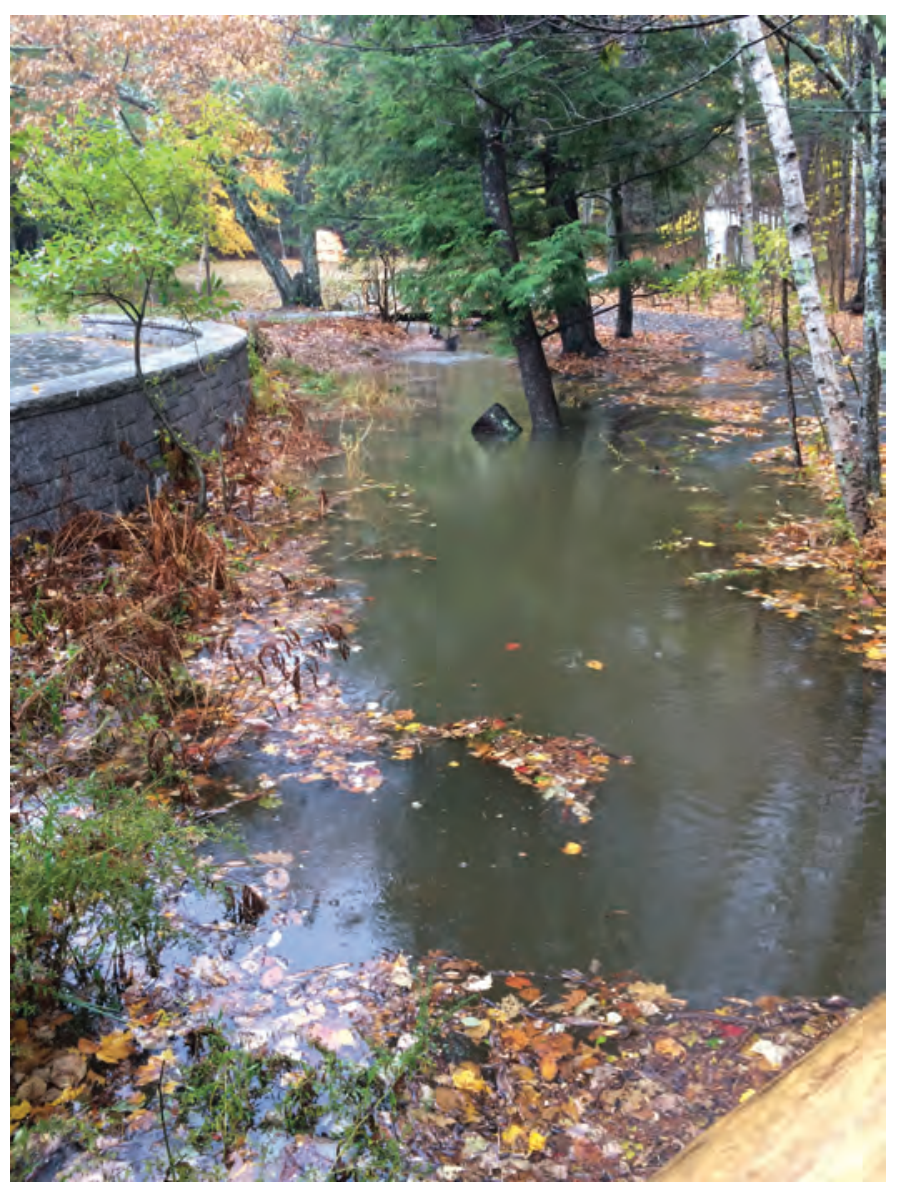

Figure 7. The Sieur de Monts tributary at the Sieur de Monts Nature Center after 3.28 inches of rainfall on October 29, 2015, Mount Desert Island, Maine.

years; 10 years of peak flow is considered the minimum for calculating peak-flow statistics at USGS streamgaging stations in order to capture wet and dry periods (Interagency Advisory Committee on Water Data, 1982). Peak flows calculated for Cromwell Brook using the Otter Creek streamgage adjusted for drainage area result in peak flow magnitudes that are considered to be unrealistically high.

In the absence of a streamgage in the watershed or in a nearby watershed with similar basin characteristics and with adequate years of record, peak flow hydrology can be estimated using regression equations with the rational method (Dunne and Leopold, 1978) or by creating a rainfall runoff model such as the National Resources Conservation TR-20 (Pilgrim and Cordery, 1993). Hodgkins and others (2007) determined that regression equations were more accurate than the rational method or the National Resources Conservation TR-20 method of estimating peak flows in Maine for streams with drainage areas of 1 to $10 \mathrm{mi}^{2}$. Statewide regression equations are typically developed using streamgages throughout the State with from 10 to 100 years of record and, thus, take wet and dry periods into account. 
Flows calculated using statistical regression equations are the best-available estimates for peak flows in the Cromwell Brook drainage basin. Instantaneous peak flows for Cromwell Brook with 2-, 5-, 10-, 25-, 50-, and 100-year recurrence intervals were computed using peak-flow regression equations that use drainage area and percentage of wetlands in the basin to determine statistical flows (Lombard and Hodgkins, 2015) (table 5). These peak-flow regression equations were designed for small ungaged streams in Maine with basins between 0.3 and $12 \mathrm{mi}^{2}$, and with wetlands between 0 and 22 percent of the basin. Equations are of this form:

$$
Q 100=238.781\left(D A^{0.817}\right)\left(10^{-0.018 w}\right),
$$

where

$$
\begin{gathered}
Q \quad \text { is the instantaneous peak flow, in cubic feet } \\
\text { per second, with a 100-year recurrence } \\
\text { interval (note that the equation has a } \\
\text { similar form but different coefficients and } \\
\text { exponents for instantaneous peak flows } \\
\text { with other recurrence intervals); } \\
\text { is the drainage area of the basin, in square } \\
\text { miles; and } \\
\text { is basin wetlands, in percent. }
\end{gathered}
$$

Drainage areas, percentage of wetlands in the basin, and flows calculated for instantaneous peak flows with from 2- to 100-year recurrence intervals were calculated for six locations in the Cromwell Brook drainage basin and are presented in table 5. These flows are used as input for the hydraulic model.

To characterize typical high-flow spring conditions, April daily mean streamflows equaled or exceeded 5 -percent of the time (95th percentile April flows) were computed using statewide monthly regression equations (Dudley, 2015) that use drainage area, percentage of open water, and the distance from the basin centroid to a reference line in the Gulf of Maine ("distance to the coast") (table 5). Although the equation to estimate the 95th percentile streamflow was not developed for use on basins less than $15 \mathrm{mi}^{2}$, and the streamflow estimates will be of unknown accuracy, it is the best-available equation for small basins in Maine. April flows computed for Cromwell Brook using the regression equations corresponded well with April flows calculated from Cromwell Brook using the Otter Creek streamgage adjusted for drainage area. The 95 th percentile April streamflows likely correspond better than flood flows

\begin{tabular}{|c|c|c|c|c|c|c|c|c|c|c|c|}
\hline \multirow{2}{*}{ Location } & \multirow{2}{*}{$\begin{array}{l}\text { Drainage } \\
\text { area } \\
\left(\mathrm{mi}^{2}\right)\end{array}$} & \multirow{2}{*}{$\begin{array}{l}\text { Percent- } \\
\text { age of } \\
\text { wet- } \\
\text { lands }\end{array}$} & \multirow{2}{*}{$\begin{array}{l}\text { Percent } \\
\text { open } \\
\text { water }\end{array}$} & \multirow{2}{*}{$\begin{array}{l}\text { Distance } \\
\text { to the } \\
\text { coast } \\
\text { (mi) }\end{array}$} & \multirow{2}{*}{$\begin{array}{c}\text { 95th } \\
\text { percen- } \\
\text { tile April } \\
\text { streamflow } \\
\left(\mathrm{ft}^{3} / \mathrm{s}\right)\end{array}$} & \multicolumn{6}{|c|}{$\begin{array}{l}\text { Estimated peak streamflow for the } \\
\text { recurrence interval }\left(\mathrm{ft}^{3} / \mathrm{s}\right)\end{array}$} \\
\hline & & & & & & 2 & 5 & 10 & 25 & 50 & 100 \\
\hline $\begin{array}{l}\text { Cromwell Brook at the Tarn } \\
\text { outflow }\end{array}$ & 0.3 & 12.3 & 4.98 & 25 & 4.39 & 16.0 & 24.7 & 30.7 & 39.9 & 46.0 & 53.7 \\
\hline $\begin{array}{l}\text { Cromwell Brook downstream } \\
\text { from the confluence with } \\
\text { the Sieur de Monts tributary }\end{array}$ & 0.7 & 12.2 & 2.13 & 25 & 12.5 & 31.6 & 49.0 & 61.0 & 79.6 & 92.0 & 108 \\
\hline $\begin{array}{l}\text { Cromwell Brook at Park Loop } \\
\text { Road (the outflow from } \\
\text { Great Meadow wetland) }\end{array}$ & 1.2 & 18.7 & 1.24 & 25 & 22.2 & 38.9 & 59.6 & 73.2 & 95.7 & 109 & 128 \\
\hline $\begin{array}{l}\text { Sieur de Monts tributary at the } \\
\text { mouth }\end{array}$ & 0.2 & 19.2 & 0.00 & 25 & 5.08 & 9.68 & 14.7 & 17.9 & 23.3 & 26.4 & 28.9 \\
\hline
\end{tabular}
to the Otter Creek streamgage because they are less dependent on storage. It is also more realistic to estimate an annual flow as opposed to a flood flow with a 100 -year recurrence interval based on 10 years of record. The 95th percentile April flow will be the annual flow referred to throughout the remainder of the report.

Table 5. Streamflows for Cromwell Brook from the outflow of the Tarn to the confluence with Kebo Brook and for the mouth of the Sieur de Monts tributary, Mount Desert Island, Maine.

$\left[\mathrm{mi}^{2}\right.$, square mile; mi, mile; Distance to the coast, the distance from the basin centroid to a reference line in the Gulf of Maine; $\mathrm{ft}^{3} / \mathrm{s}$, cubic foot per second] 


\section{Hydraulic Model}

The HEC-RAS, version 4.1.0 step-backwater hydraulic model (U.S. Army Corps of Engineers, 2010b) was built and used to characterize flooding in Cromwell Brook and the Sieur de Monts tributary (fig. 1). The model was used to determine water-surface elevations for the 95 th percentile April streamflow and for peak streamflows with 2-, 5-, 10-, 25-, 50-, and 100-year recurrence intervals (figs. 8 through 14, in back of report). In addition, threshold flows for flooding in the region were calculated; for example, to estimate the peak streamflow that first causes flooding over Park Loop Road, and the peak streamflow that first causes flooding in the Sieur de Monts Nature Center because of backwater from the Park Loop Road culvert is calculated. The model calculates water-surface elevations at each of the input cross sections and hydraulic structures using steady-state, 1-dimensional flow assumptions. The hydraulic model for Cromwell Brook includes all the surveyed structures and natural cross sections on Cromwell Brook and the Sieur de Monts tributary as outlined above (see the "Survey of Elevation Reference Marks, Hydraulic Structures, Underwater Points, and Ground Control Points" section).

The hydraulic model estimates energy losses that result from frictional resistance exerted by a channel on flow and from expansion and contraction of flow at structures. The channel friction losses are quantified using the Manning's roughness coefficient ( $n$-value); $n$-values for the channel were estimated between 0.045 and 0.055 based on field observations, high-resolution aerial photographs, and other studies on wetland streams with flow depths greater than $1 \mathrm{ft}$ (Natural Resources Conservation Service, 2008). The $n$-values were assumed to be constant throughout the year and with varying stages. Much of the overbank in Great Meadows was characterized by $3-4$-ft tall grasses with estimated $n$-values from 0.07 to 0.1 . Channel bed slopes were calculated based on channel inverts (lowest point in each cross section) in the model. A normal depth slope of 0.001 was used as a starting water-surface elevation at the confluence with Kebo Brook. A sensitivity analysis was completed using a range of starting water-surface slopes to ensure that the chosen slope did not influence conclusions about flooding in the Sieur de Monts area. The model was run under steady-state flow conditions using a subcritical (tranquil) flow regime. Flow through the Park Loop Road culvert is outlet controlled at all modeled flows - conveyance is controlled by downstream water-surface elevation and the area of the culvert opening.

Models are improved greatly if they are calibrated to historical observed flood data. The lack of measured peak streamflows and corresponding surveyed high-water marks in the Cromwell Brook drainage basin results in a model that is potentially less accurate. Anecdotal information about water levels during rainstorms in the watershed were used to put the calculated hydrology and model into context.

\section{Flood-Inundation Mapping}

The USGS created flood-inundation maps using a Geographic Information System (GIS) for all modeled watersurface profiles by combining the HEC-RAS model output with a DEM surface created using the adjusted lidar data. Estimated flood-inundation boundaries for each simulated profile were developed with HEC-RAS, which provides floodinundation boundaries resulting from the hydraulic model that can be exported to a GIS (U.S. Army Corps of Engineers, 2010b). Shapefile polygons of the inundated areas for each profile were created using an extension of ArcGIS designed to process geospatial data from HEC-RAS (HEC-GeoRAS) (U.S. Army Corps of Engineers, 2010a) and finalized for publication in the ArcMap application of ArcGIS. The maps depict flood plain boundaries of flows with 2-, 5-, 10-, 25-, 50 -, and 100-year recurrence intervals (figs. 15-20, in back of report).

The flood-inundation areas are overlaid on high-resolution, georeferenced, aerial photographs of the study area. Bridge surfaces are not shown as inundated up to the lowest flood stage that either intersects the lowest structural chord of the bridge or completely inundates one or both approaches to the culvert. In these latter circumstances, the bridge surface is depicted as being inundated. A shaded building should not be interpreted to mean that the structure is completely submerged but rather that bare-Earth surfaces near the building are inundated.

\section{Disclaimer for Flood-Inundation Maps}

The flood-inundation maps should not be used for navigation, regulatory, permitting, or other legal purposes. The USGS provides these maps "as is" for a quick-reference, emergency planning tool but assumes no legal liability or responsibility resulting from the use of this information.

\section{Uncertainties and Limitations Regarding Use of Flood-Inundation Maps}

Although the flood-inundation maps represent the boundaries of inundated areas with a distinct line, some uncertainty is associated with these maps. The flood boundaries shown were estimated based on flood hydrology estimated using regression equations. Water-surface elevations along the stream reaches were estimated by steady-state hydraulic modeling, assuming unobstructed flow. The hydraulic model represents land-cover characteristics and bridge, dam, levee, or other hydraulic structures existing as of 2015. Unique meteorological factors (timing and distribution of precipitation) may cause actual streamflows along the modeled reach to vary from those assumed during a flood, which may lead to deviations in the water-surface elevations and inundation boundaries shown. Additional areas may be flooded because 
of unanticipated conditions, such as changes in the streambed elevation or roughness, backwater into major tributaries along a main stem river, or backwater from localized debris or beaver dams. The accuracy of the floodwater extent portrayed on these maps will vary with the accuracy of the DEM used to simulate the land surface.

\section{Modeled Flooding}

The Sieur de Monts tributary enters Cromwell Brook in the Great Meadow wetland downstream from the Sieur de Monts Nature Center (fig. 1). Surveyed elevations throughout the watershed indicated that channel bed slopes averaged 0.001 in the reach downstream from Park Loop Road (fig. 8, in back of report), and 0.02 in the upstream reach of Cromwell Brook (between the Tarn and Sieur de Monts area). Cromwell Brook has a slope of 0.005 in the $600 \mathrm{ft}$ just upstream from the confluence (fig. $8 A$, in back of report), and the Sieur de Monts tributary has a slope of 0.002 in the $600 \mathrm{ft}$ just upstream from the confluence (fig. $8 B$, in back of report). Because of the differences of slope, channel elevations at the Nature Center on the tributary are about $3 \mathrm{ft}$ lower in elevation than elevations on Cromwell Brook near the Nature Center parking area, the same distance upstream from the confluence (figs. 8 through 14, in back of report); thus, backwater from the Great Meadow wetland has a much greater effect on the tributary than it does on Cromwell Brook near the Nature Center parking area for streamflows with 10- and 25-year recurrence intervals (figs. 17 and 18 , in back of report).

The model indicates that backwater from Great Meadows wetland first causes flooding on the Sieur de Monts tributary around the Sieur de Monts Nature Center at a 5-year flow (figs. 10 and 16, in back of report); and is backed up into the Nature Center parking area during 10-year flows and greater (figs. 11 and 17, in back of report). All foot bridges and culverts of the Sieur De Monts tributary and parking area around the Nature Center are underwater because of backwater from the Great Meadow wetland for flows in the 25-year recurrence interval and greater (figs. 12 and 18, in back of report). The 50- and 100-year flows inundate the entire Great Meadow wetland and Sieur de Monts area (figs. 13, 14, 19, 20, in back of report); and 100-year flows also go over Park Loop Road (figs. 14 and 20, in back of report).

Modeled flows of roughly 140 cubic feet per second $\left(\mathrm{ft}^{3} / \mathrm{s}\right)$ at Park Loop Road (over a 100-year flow) are the flows that first start covering the road. The National Park Service staff who have worked at Acadia National Park for more than 20 years have not observed water flowing over the road despite observing multiple floods around the Sieur de Monts Nature Center. The model also indicates that flows of 80 to $85 \mathrm{ft}^{3} / \mathrm{s}$ (between 10- and 25-year flows) are the flows at which the Nature Center parking area first begins to flood if water backs up from Park Loop Road.

\section{Culvert Design Considerations}

Hydrologic and hydraulic analyses of Cromwell Brook indicate that the Park Loop Road culvert exacerbates flooding and is likely undersized for large floods (about 10-year recurrence interval or greater). Current (2016) best practices for culvert design and sizing that take fish and other aquatic organisms into account, as well as flood flows, recommend culvert sizes of at least 1.2 times bankfull width that are also designed to pass the flood with a 50-year recurrence interval (Maine Department of Transportation, 2008). Multiple barrel culverts are discouraged because the stream velocities and debris problems are often an impediment to fish and wildlife passage, and they can be prone to scouring around inlets and outlets (Singler and others, 2012). Multiple smaller barrels are also more easily plugged by beavers, which are a primary concern in the Great Meadow.

It is difficult to determine what bankfull width at this location might be due to the wetland; however, regression equations developed for coastal and central Maine (Dudley, 2004) estimate that a drainage basin size of $1.2 \mathrm{mi}^{2}$ (the drainage basin size of Cromwell Brook at Park Loop Road) would result in a bankfull width of about $8.5 \mathrm{ft}$ and, thus, a culvert diameter of a minimum of $10 \mathrm{ft}$ (1.2 times bankfull width).

\section{Park Loop Road Culvert Size Scenario Testing}

Two culvert sizes at Park Loop Road were tested using the hydraulic model to determine the resulting effect on flooding in the Sieur de Monts area. All scenarios are approximate and assume all other conditions remain the same.

Replacing the 3.3-ft Park Loop Road culvert with a larger culvert has the potential to mitigate the effects of floods with 10 -year recurrence intervals and greater; consequently, this culvert was replaced with 8 - and 10 -ft culverts in the model to test the potential effects on flooding. Culvert inverts were held constant. Resulting elevations in the Sieur de Monts tributary just upstream from the Great Meadow wetland and adjacent to the Sieur de Monts Nature Center (tables 6 and 7) can be compared to ground elevations (fig. 21) to determine the estimated extent of flooding under these different scenarios.

Increasing the size of the Park Loop Road culvert from $8 \mathrm{ft}$ to $10 \mathrm{ft}$ diameter has minimal effect on flood elevations in the Sieur de Monts area resulting from peak flows with as much as a 5-year recurrence interval $(0.0$ to $0.6 \mathrm{ft}$ differences, tables 6 and 7). Increasing the size of the Park Loop Road culvert does have an effect on flood elevations in the Sieur de Monts area resulting from flows with 10- and 25-year recurrence intervals, but resulting flood elevations are similar whether or not the culvert diameter is increased to 8 or $10 \mathrm{ft}$. Increasing the culvert diameter to 8 or $10 \mathrm{ft}$ lowers the elevation just upstream from the Great Meadow wetland by $1.8 \mathrm{ft}$ for the 10-year flow and $4.2 \mathrm{ft}$ for the 25 -year flow. Increasing the culvert diameter also lowers the elevation next to the Sieur de Monts Nature Center by $0.6 \mathrm{ft}$ for the 10 -year flow and 
Table 6. Flood elevations at the Sieur de Monts Nature Center for increasing culvert sizes at the Park Loop Road, Mount Desert Island, Maine.

[ft, foot; NAVD 88, North American Vertical Datum of 1988]

\begin{tabular}{cccc}
\hline \multirow{2}{*}{$\begin{array}{c}\text { Flow } \\
\text { recurrence } \\
\text { interval } \\
\text { (years) }\end{array}$} & \multicolumn{3}{c}{$\begin{array}{c}\text { Flood elevations at the } \\
\text { Sieur de Monts Nature Center, } \\
\text { in ft NAVD 88 }\end{array}$} \\
\cline { 2 - 4 } & $\begin{array}{c}\text { 3.3-ft } \\
\text { diameter } \\
\text { culvert }\end{array}$ & $\begin{array}{c}\text { 8-ft } \\
\text { diameter } \\
\text { culvert }\end{array}$ & $\begin{array}{c}\text { 10-ft } \\
\text { diameter } \\
\text { culvert }\end{array}$ \\
\hline 2 & 62.0 & 62.0 & 62.0 \\
5 & 62.4 & 62.3 & 62.3 \\
10 & 63.1 & 62.5 & 62.5 \\
25 & 65.5 & 62.7 & 62.7 \\
50 & 67.2 & 62.8 & 62.8 \\
100 & 67.7 & 62.9 & 62.9 \\
\hline
\end{tabular}

$2.8 \mathrm{ft}$ for the 25 -year flow. Increasing the diameter of the Park Loop Road culvert has the greatest effect on flood elevations in the Sieur de Monts area resulting from flows with 50- and 100-year recurrence intervals. For 50-year flows, the flood elevation is lowered by 5.8 and $5.9 \mathrm{ft}$ with an 8 - or $10-\mathrm{ft}$ culvert, respectively, just upstream from the Great Meadow wetland and by $4.4 \mathrm{ft}$ for 8 - and $10-\mathrm{ft}$ culverts at the Nature Center. For 100-year flows, the flood elevations are lowered by 6.0 and $6.1 \mathrm{ft}$ with 8 - or $10-\mathrm{ft}$ culverts, respectively, just upstream from the Great Meadow wetland and by $4.7 \mathrm{ft}$ for 8 - and $10-\mathrm{ft}$ culverts at the Nature Center (tables 6 and 7).

Flood-inundation maps show the flooded area in the Great Meadow wetland and at the Sieur de Monts Nature Center resulting from the existing 3.3-ft culvert and an enlarged $10-\mathrm{ft}$ culvert at Park Loop Road in comparison to each other for floods of 10-, 25-, and 100-year recurrence intervals (figs. 22-24, in back of report). Flood-inundation maps from the model with an 8 - $\mathrm{ft}$ culvert at Park Loop Road are not shown because they are chiefly the same as those for the $10-\mathrm{ft}$ culvert. These maps give an approximate indication of how much the flooded area is reduced with the increased culvert at the Park Loop Road. It does not indicate the depth of the flooding at these locations.

\section{Effects on Great Meadow Wetland Hydrology from Culvert Replacement}

The model indicates that increasing the size of the culvert at Park Loop Road but ensuring that the invert of the culvert stays at the same elevation as the current culvert results in minimal changes to the water-surface elevations of the Great Meadow wetland at the 95th percentile April flow, and 2- and 5-year peak flows; for example, the modeled flood elevation
Table 7. Flood elevations for the Sieur de Monts tributary just upstream from the Great Meadow wetland for increasing culvert sizes at the Park Loop Road, Mount Desert Island, Maine.

[ft, foot; NAVD 88, North American Vertical Datum of 1988]

\begin{tabular}{cccc}
\hline \multirow{2}{*}{$\begin{array}{c}\text { Flow } \\
\text { recurrence } \\
\text { interval } \\
\text { (years) }\end{array}$} & $\begin{array}{c}\text { Flood elevations at the Sieur de Monts tributary } \\
\text { just upstream from the Great Meadow wetland, } \\
\text { in ft NAVD 88 }\end{array}$ \\
\cline { 2 - 4 } & $\begin{array}{c}\text { 8.3-ft } \\
\text { diameter } \\
\text { culvert }\end{array}$ & $\begin{array}{c}\text { 8-ft } \\
\text { diameter } \\
\text { culvert }\end{array}$ & $\begin{array}{c}\text { 10-ft } \\
\text { diameter } \\
\text { culvert }\end{array}$ \\
\hline 2 & 61.1 & 61.1 & 61.1 \\
5 & 61.7 & 61.1 & 61.1 \\
10 & 63.0 & 61.2 & 61.2 \\
25 & 65.5 & 61.3 & 61.3 \\
50 & 67.2 & 61.4 & 61.3 \\
100 & 67.7 & 61.6 & 61.5 \\
\hline
\end{tabular}

Table 8. Flood elevations for Cromwell Brook just upstream from the Park Loop Road for increasing culvert sizes at Park Loop Road, Mount Desert Island, Maine.

[ft, foot; NAVD 88, North American Vertical Datum of 1988]

\begin{tabular}{cccc}
\hline \multirow{2}{*}{$\begin{array}{c}\text { Flow } \\
\text { recurrence } \\
\text { interval } \\
\text { (years) }\end{array}$} & \multicolumn{3}{c}{$\begin{array}{c}\text { Flood elevations on Cromwell Brook } \\
\text { just upstream from Park Loop Road, } \\
\text { in ft NAVD 88 }\end{array}$} \\
\cline { 2 - 4 } & $\begin{array}{c}\text { 8.3-ft } \\
\text { diameter } \\
\text { culvert }\end{array}$ & $\begin{array}{c}\text { 8-ft } \\
\text { diameter } \\
\text { culvert }\end{array}$ & $\begin{array}{c}\text { 10-ft } \\
\text { diameter } \\
\text { culvert }\end{array}$ \\
\hline 2 & 60.0 & 59.3 & 59.3 \\
5 & 61.7 & 59.9 & 59.8 \\
10 & 63.0 & 60.3 & 60.2 \\
25 & 65.5 & 60.8 & 60.7 \\
50 & 67.2 & 61.1 & 60.9 \\
100 & 67.7 & 61.4 & 61.3 \\
\hline
\end{tabular}

for the 95th percentile April flow at the Sieur de Monts Nature Center and tributary just upstream from the Great Meadow wetland are the same for the current 3.3-ft culvert and for enlarged 8- and 10-ft culverts (tables 6 and 7). Modeled flood elevations decrease by only $0.3 \mathrm{ft}$ just upstream from the Park Loop Road by enlarging the culvert to 8 or $10 \mathrm{ft}$ (table 8). Increasing the culvert to 8 or $10 \mathrm{ft}$ lowers the water-surface elevation of the 2-year peak flow by $0.7 \mathrm{ft}$ and lowers the water-surface elevation of the 50 -year flow by 6.2 and $6.3 \mathrm{ft}$, respectively, just upstream from the Park Loop Road culvert (table 8). These results are an oversimplification of a complex wetland system, especially for the lower flows. The installation of streamgages and groundwater wells and the collection 
$68^{\circ} 12^{\prime} 30^{\prime \prime}$

$68^{\circ} 12^{\prime} 25^{\prime \prime}$

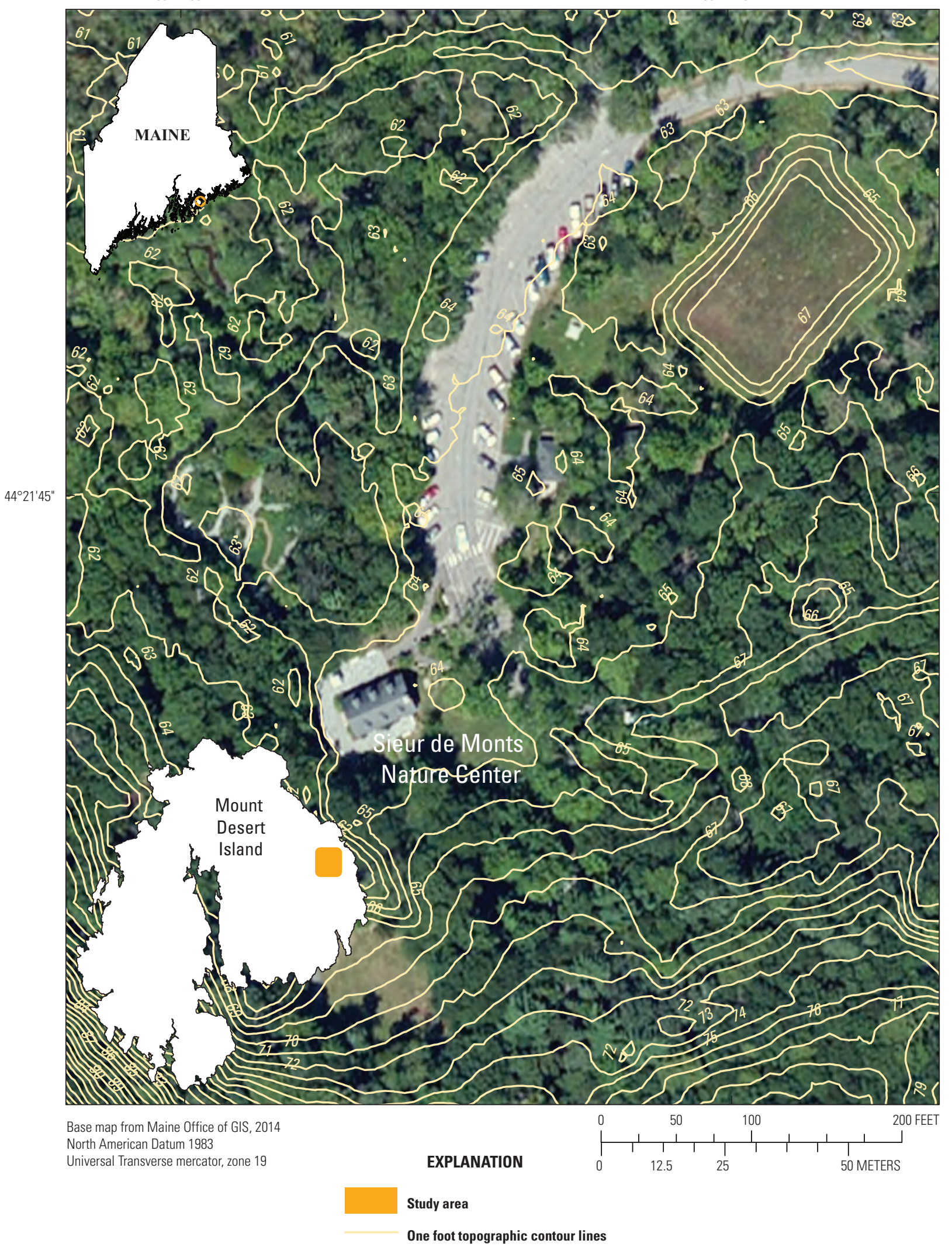

Figure 21. Contour elevations around the Sieur de Monts Nature Center, Mount Desert Island, Maine. 
of hydrologic data over time would allow for better understanding of water storage and runoff in the Great Meadow wetland. Evaluating the effect that decreased flood elevations as the result of culvert enlargement would have on the meadow ecology is beyond the scope of this work.

\section{Effects on Downstream Flooding from Culvert Replacement}

Increasing the size of the Park Loop Road culvert has the potential to affect flooding downstream from the culvert by changing the timing and magnitudes of peak streamflows. The existing 3.3-ft culvert attenuates the flow through and downstream from it by temporarily storing water in the Great Meadow wetland. Rainfall runoff flowing through an enlarged culvert would peak sooner and be greater in magnitude than it would have with the existing culvert; therefore, runoff would have the potential to increase channel erosion near and downstream from Park Loop Road. Potential increases in peak flows or channel erosion will decrease as distance downstream from the culvert increases. Routing the water through a reservoir or wetland to obtain maximum peak flow as a result of outflow culverts of various sizes would require an inflow hydrograph, a peak rate of inflow, and the lag time or time to peak for the drainage basin; none of this information is currently (2016) available.

\section{Influence of Beaver Dams}

The hydrology and hydraulics of the Great Meadow wetland is complicated greatly by the presence of beaver dams. Beavers are extremely active in the area and have created dams and lodges throughout the Great Meadow wetland in numerous locations over the years. Acadia National Park staff have hypothesized that beaver dams have the potential to aggravate flooding in the Great Meadow wetland and at the Sieur de Monts Nature Center (fig. 1).

Beaver dams would be most likely to aggravate flooding from peak streamflows with from 1- to 5-year recurrence intervals. For peak flows that have from 1- to 5-year recurrence intervals, beaver dams have the potential to create backwater into the Sieur de Monts area, including the parking area, Nature Center, and septic tank up to the elevation of the beaver dam itself. Streambanks throughout the Great Meadow wetland range from about 60 to $61 \mathrm{ft}$ in elevation. Although backwater from the Great Meadow wetland floods the Acadia Wild Gardens at Sieur de Monts at elevations of 62.0 to $62.4 \mathrm{ft}$, backwater does not start to flood the parking lot and septic system at Sieur de Monts until it reaches elevations of roughly $63.3 \mathrm{ft}$ or more (fig. 21); thus, it is unlikely that beaver dams by themselves are responsible for the flooding in and around the Nature Center for annual rainstorms and rainstorms with from 2- to 5-year recurrence intervals. These rainstorms can, however, have a large effect on the initial conditions before a large rainstorm. Beaver dams can create initial starting water-surface elevations that stall drainage in the Sieur de Monts area and aggravate flooding during rainstorms that follow in quick succession. Rainstorms with recurrence intervals greater than 10 years will likely drown out or destroy the beaver dams because the elevation of the 10 -year water surface throughout the Great Meadow wetland would be greater than or equal to $2 \mathrm{ft}$ or more than the height of the streambanks.

\section{Overland Flow}

Modeling Cromwell Brook through the Great Meadow wetland indicates that for annual rainstorms and rainstorms with from 2- to 5-year recurrence intervals, the culvert at the Park Loop Road is likely not responsible for the frequent flooding observed upstream at the Sieur de Monts Nature Center; however, overland flow has been observed and documented more frequently than every 10 years around the Sieur de Monts Nature Center. Rainstorms producing 3 in. of rain on June 21, 2015, and 3.28 in. of rain on October 29, 2015 , resulted in small amounts of overland flow near the Sieur de Monts Nature Center including the parking area (figs. 5 and 6) (National Atmospheric Deposition Program, 2015). Rainfall totals 3 in. during 24-hour period on average once every year according to current (2015) frequency curves (National Oceanic and Atmospheric Administration, 2015). Examination of the drainage system around the Sieur de Monts Nature Center shows a complicated system of culverts that are not properly installed (fig. 25). Although an analysis of the local hydraulic conditions around the Sieur de Monts Nature Center is beyond the scope of this report, flooding around the Nature Center is likely an issue of overland flow resulting from quick runoff from the steep slopes of Dorr Mountain flowing into the Great Meadow wetland area, which has little slope and poor drainage aggravated by beaver dams holding water in the Great Meadow wetland. Improving drainage efficiency through this area would likely reduce flooding from frequent high-intensity rainstorms.

\section{Additional Work}

The Cromwell Brook drainage basin through the Tarn and Great Meadow wetland is a unique system in Acadia National Park in Maine; streamflow estimates based on other nearby drainage basins do not correspond well to the hydrology of this system. Additional hydrologic data would be extremely helpful in understanding flooding in this type of complicated drainage basin in the future. Specifically, the installation of continuous-record or flood peak crest-stage gages, as well as precipitation gages in the drainage basin would allow for the calibration of hydraulic models, and the calculation of the lag time or time to peak flow of the drainage basin, which could offer insight into wetland storage and how downstream flooding may be exacerbated by different scenarios. In addition, 

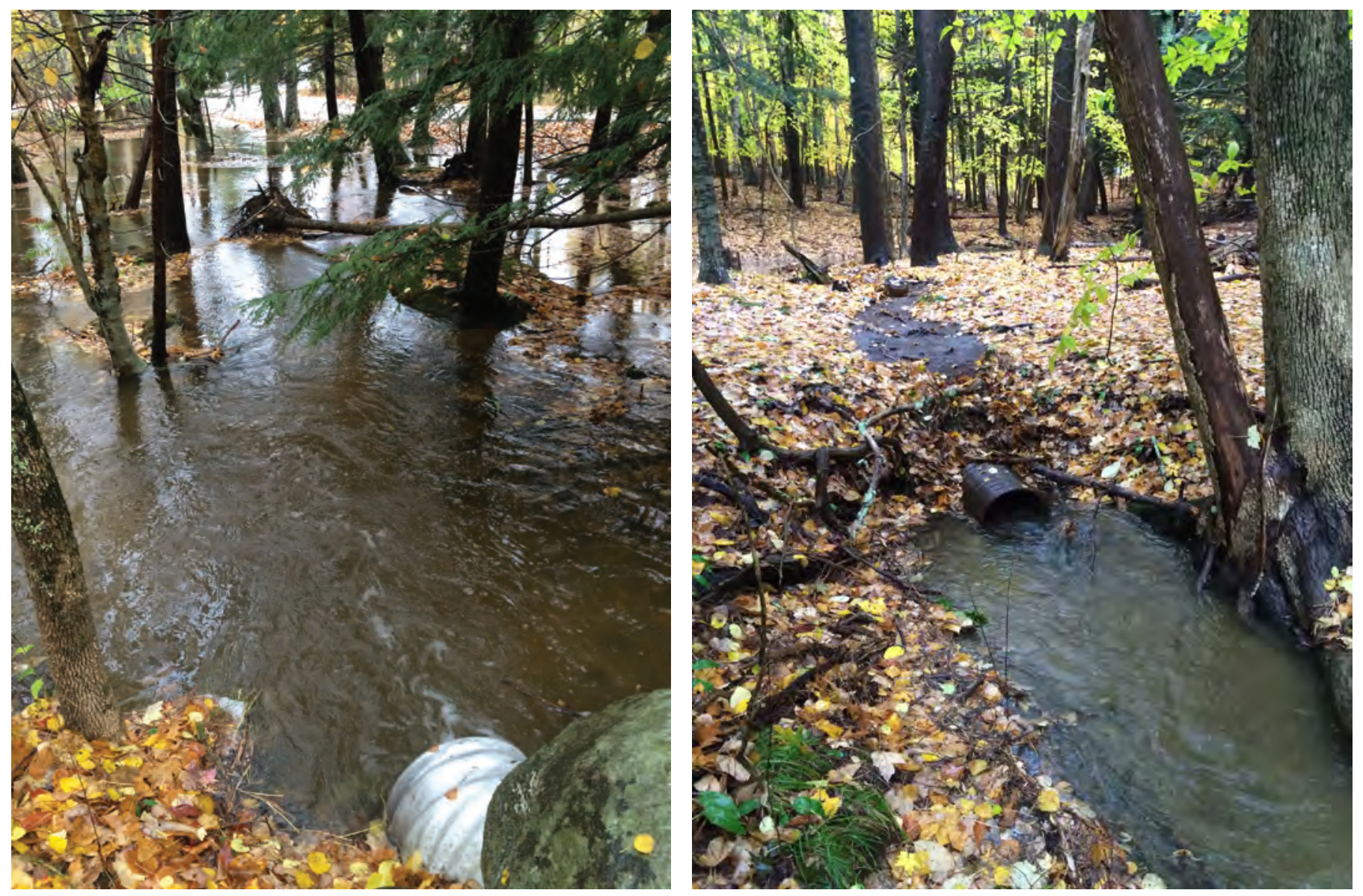

Figure 25. The culvert drainage area upstream from the Sieur de Monts Nature Center after 3.28 inches of rainfall on 0ctober 29, 2015, Mount Desert Island, Maine (Photographs by Brian Henkel, Friends of Acadia).

documenting and surveying high-water marks and taking streamflow measurements during and after large floods provides critical data for the calibration of the hydraulic models.

\section{Summary}

Flooding at the Sieur de Monts Nature Center at Acadia National Park on Mount Desert Island, Maine, has increasingly become a problem for the Acadia National Park. Park staff have noted that historic monuments and critical infrastructure, including the Sieur de Monts Nature Center, the parking lot and septic system servicing the Sieur de Monts Nature Center, and Park Loop Road, are flooding at increased frequency than has been noted in the past. Changes in precipitation frequency curves between 1993 and 2015 support the observations of the Acadia National Park staff who have observed that rainstorms producing 3 inches of rain, which have the potential to cause overland flow and flooding problems around the Nature Center, are happening more frequently at Acadia National Park. Hydrologic and hydraulic analyses of this area indicate that the Park Loop Road culvert exacerbates flooding from large floods with recurrence intervals of 10 years or greater, and is thus undersized for these large flood events.

Increasing the Park Loop Road culvert diameter to 8 feet or greater would allow for the passage of a 100 -year flood and greatly reduce flooding caused by backwater up through the Great Meadow wetland into the area around the Sieur de Monts Nature Center during large floods. A culvert that is 10 feet in diameter or greater would also ensure that adequate stream banks are provided in the crossing for species that use riparian habitat as travel corridors.

Enlarging the culvert at Park Loop Road would likely have little effect on flood elevations for more frequent floods. The frequent overland flooding that happens in the vicinity of the Sieur de Monts Nature Center could potentially be mitigated by better drainage systems around the Nature Center, the design of which is beyond the scope of this project. The removal of beaver dams could have the potential to reduce the extent of flooding from 1- to 5-year recurrence intervals caused by rainstorms in quick succession. 


\section{References Cited}

Bowen, Z.H., and Waltermire, R.G., 2002, Evaluation of light detection and ranging (lidar) for measuring river corridor topography: Journal of the American Water Resources Association, v. 38, no. 1, p. 33-41. [Also available at http://dx.doi.org/10.1111/j.1752-1688.2002.tb01532.x.]

Dudley, R.W., 2004, Hydraulic-geometry relations for rivers in coastal and central Maine: U.S. Geological Survey Scientific Investigations Report 2004-5042, 30 p. [Also available at http://pubs.usgs.gov/sir/2004/5042/.]

Dudley, R.W., 2015, Regression equations for monthly and annual mean and selected percentile streamflows for ungaged rivers in Maine: U.S. Geological Survey Scientific Investigations Report 2015-5151, 35 p., accessed June 2016 at http://dx.doi.org/10.3133/sir20155151.

Dunne, Thomas, and Leopold, L.B., 1978, Water in environmental planning: San Francisco, Calif., W.H. Freeman and Company, $818 \mathrm{p}$.

England, J.F., Jr., Cohn, T.A., Faber, B.A., Stedinger, J.R., Thomas Jr., W.O., Veilleux, A.G., Kiang, J.E., and Mason, R.R., draft, Guidelines for determining flood flow frequency-Bulletin 17C: U.S. Geological Survey Techniques and Methods, book 4, chap. B17, 156 p., accessed August 2016 at http://acwi.gov/hydrology/ Frequency/b17c/index.html.

Groisman, P.Y., Knight, R.W., Karl, T.R., Easterling, D.R., Sun, Bomin, and Lawrimore, J.H., 2004, Contemporary changes of the hydrological cycle over the contiguous United States-Trends derived from in situ observations: Journal of Hydrometeorology, v. 5, p. 64-85. [Also available at http://dx.doi.org/10.1175/1525-7541(2004)005 \%3C0064:СCOTHC\%3E2.0.CO;2.]

Heidemann, H.K., 2014, Lidar base specification (ver. 1.2, November 2014): U.S. Geological Survey Techniques and Methods, book 11, chap. B4, 67 p. with appendixes, accessed April 2015 at http://dx.doi.org/10.3133/tm11B4.

Hladik, Christine, and Alber, Merryl, 2012, Accuracy assessment and correction of a LIDAR-derived salt marsh digital elevation model: Remote Sensing of Environment, v. 121, p. 224-235. [Also available at http://dx.doi.org/10.1016/j.rse.2012.01.018.]

Hodgkins, G.A., Hebson, Charles, Lombard, P.J., and Mann, Alexander, 2007, Comparison of peak-flow estimation methods for small drainage basins in Maine: U.S. Geological Survey Scientific Investigations Report 2007-5170, 32 p. [Also available at http://pubs.usgs.gov/ sir/2007/5170/.]
Interagency Advisory Committee on Water Data, 1982, Guidelines for determining flood flow frequency-Bulletin 17B of the Hydrology Subcommittee: U.S. Geological Survey, Office of Water-Data Coordination, $183 \mathrm{p}$.

Karl, T.R., Knight, R.W., Easterling, D.R., and Quayle, R.G., 1996, Indices of climate change for the United States: Bulletin of the American Meteorological Society, v. 77, p. 279-292. [Also available at http://dx.doi.org/10.117 5/1520-0477(1996)077\%3C0279:IOCCFT\%3E2.0.CO;2.]

Lombard, P.J., and Hodgkins, G.A., 2015, Peak flow regression equations for small, ungaged streams in MaineComparing map-based to field-based variables: U.S. Geological Survey Scientific Investigations Report 20155049, 12 p. [Also available at http://dx.doi.org/10.3133/ sir20155049.]

Lubinski, Sara, Hop, Kevin, and Gawler, Susan, 2003, U.S. Geological Survey-National Park Service vegetation mapping program-Acadia National Park, Maine: La Crosse, Wisc., U.S. Geological Survey, 110 p. plus appendixes. [Also available at https://science.nature.nps.gov/ im/units/netn/inventory/docs/Inventory\%20Reports/ acad_veg_report.pdf.]

Maine Department of Transportation, 2008, Waterway and wildlife crossing policy and design guide-For aquatic organism, wildlife habitat, and hydrologic connectivity (3d ed., July 2008): Augusta, Maine, Maine Department of Transportation, 122 p., accessed May 2016 at http://www.conservewildlifenj.org/downloads/ cwnj_285.pdf.

National Atmospheric Deposition Program, 2015, Acadia National Park-McFarland Hill precipitation gaging data from 1981 to 1915: National Atmospheric Deposition Program Web page, accessed May 3, 2016, at http://nadp.sws.uiuc.edu/.

National Oceanic and Atmospheric Administration, 2010, 2010 USGS ARRA lidar for the northeast-Maine: Charleston, S.C., National Oceanic and Atmospheric Administration.

National Oceanic and Atmospheric Administration Coastal Services Center, 2012, Lidar 101-An introduction to lidar technology, data, and applications: Charleston, S.C., National Oceanic and Atmospheric Administration, $72 \mathrm{p}$. [Also available at https://coast.noaa.gov/data/digitalcoast/ pdf/lidar-101.pdf.]

National Oceanic and Atmospheric Administration, 2015, Precipitation-frequency atlas of the United States: Silver Spring, Md., National Oceanic and Atmospheric Administration Atlas 14, v. 10, no. 2.0, accessed on January 15, 2016, at http://www.nws.noaa.gov/oh/hdsc/PF_documents/ Atlas14_Volume10.pdf. 
National Park Service, 2009, National Park Service cultural landscapes inventory professional procedures guide: National Park Service [variously paged]. [Also available at https://www.nps.gov/oclp/CLI\%20 PPG_January2009_small.pdf.]

Natural Resources Conservation Service, 2008, Wetland restoration, enhancement, or creation, chap. 13 of Part 650-Engineering field handbook: U.S. Department of Agriculture, 78 p. [Also available at http://directives.sc.egov.usda.gov/ OpenNonWebContent.aspx? content=17765.wba.]

New York State Department of Environmental Conservation, 2015, New York State stormwater management design manual: New York State Department of Environmental Conservation Web page, accessed June 16, 2016, at http://www.dec.ny.gov/chemical/29072.html.

Pilgrim, D.H., and Cordery, I., 1993, Flood runoff, in Maidment, D.R., ed., Handbook of Hydrology: New York, McGraw-Hill, Inc., p. 9.1-9.42.

Sadro, Steven, Gastil-Buhl, Mary, and Melack, John, 2007, Characterizing patterns of plant distribution in a southern California saltmarsh using remotely sensed topographic and hyperspectral data and local tidal fluctuations: Remote Sensing of Environment, v. 110, no. 2, p. 226-239. [Also available at http://dx.doi.org/10.1016/j.rse.2007.02.024.]
Singler, Amy, Graber, Brian, and Banks, Carrie, 2012, Massachusetts stream crossing handbook ( $2 \mathrm{~d}$ ed.): Massachusetts Executive Office of Energy and Environmental Affairs, Department of Fish and Game, Division of Ecological Restoration, 13 p. [Also available at http://www.mass.gov/ eea/docs/dfg/der/pdf/stream-crossings-handbook.pdf.]

Toyra, Jessika, Pietroniro, Alain, Hopkinson, Christopher, and Kalbfleisch, William, 2003, Assessment of airborne scanning laser altimetry (lidar) in deltaic wetland environment: Canadian Journal of Remote Sensing, v. 29, no. 6, p. 718728. [Also available at http://dx.doi.org/10.5589/m03-040.]

U.S. Army Corps of Engineers, 2010a, HEC-GeoRAS 4.2.93 for ArcGIS 9.3: U.S. Army Corps of Engineers software, accessed June 5, 2015, at http://www.hec.usace.army.mil/ software/hec-georas/downloads.aspx.

U.S. Army Corps of Engineers, 2010b, HEC-RAS 4.1: U.S. Army Corps of Engineers software, accessed June 16, 2015, at http://www.hec.usace.army.mil/software/hec-ras/ downloads.aspx.

Wilks, D.S., and Cember, R.P., 1993, Atlas of precipitation extremes for the northeastern United States and southeastern Canada: Northeast Regional Climate Center, Cornell University Publication no. RR 93-5, 40 p. [Also available at http://www.nrcc.cornell.edu/services/research/reports/ RR_93-5.pdf.] 

Figures 8-20, 22-24 

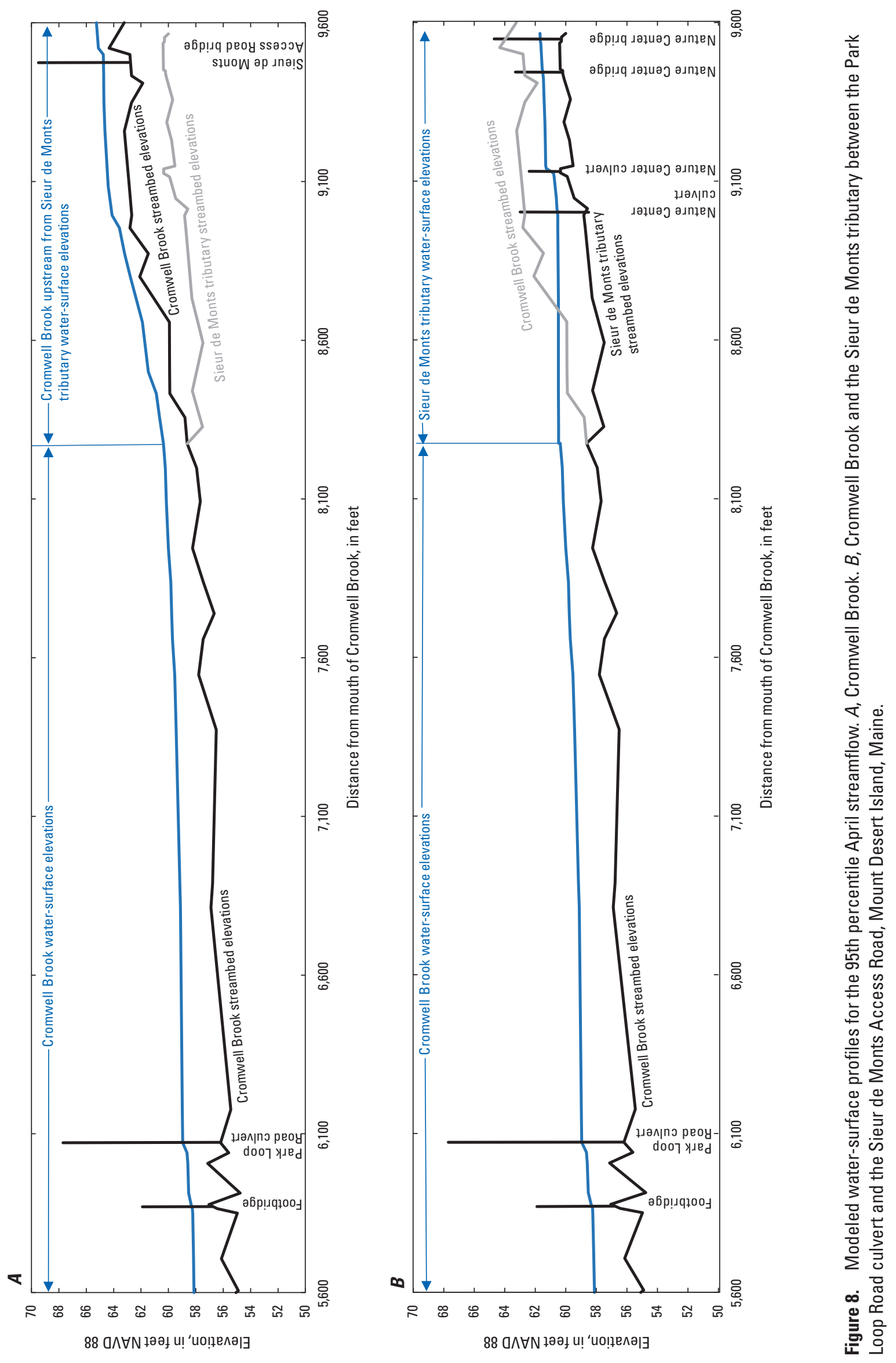

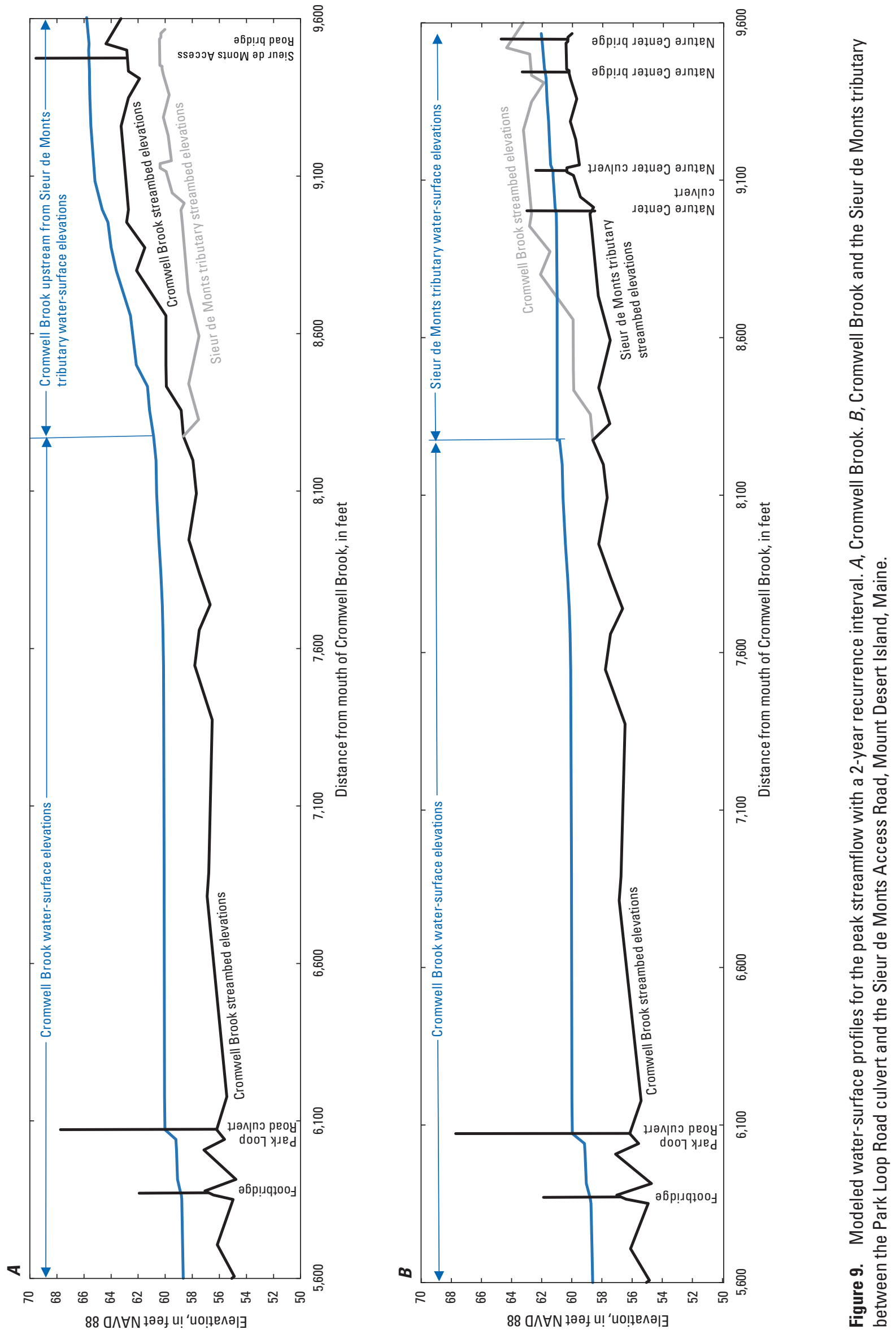

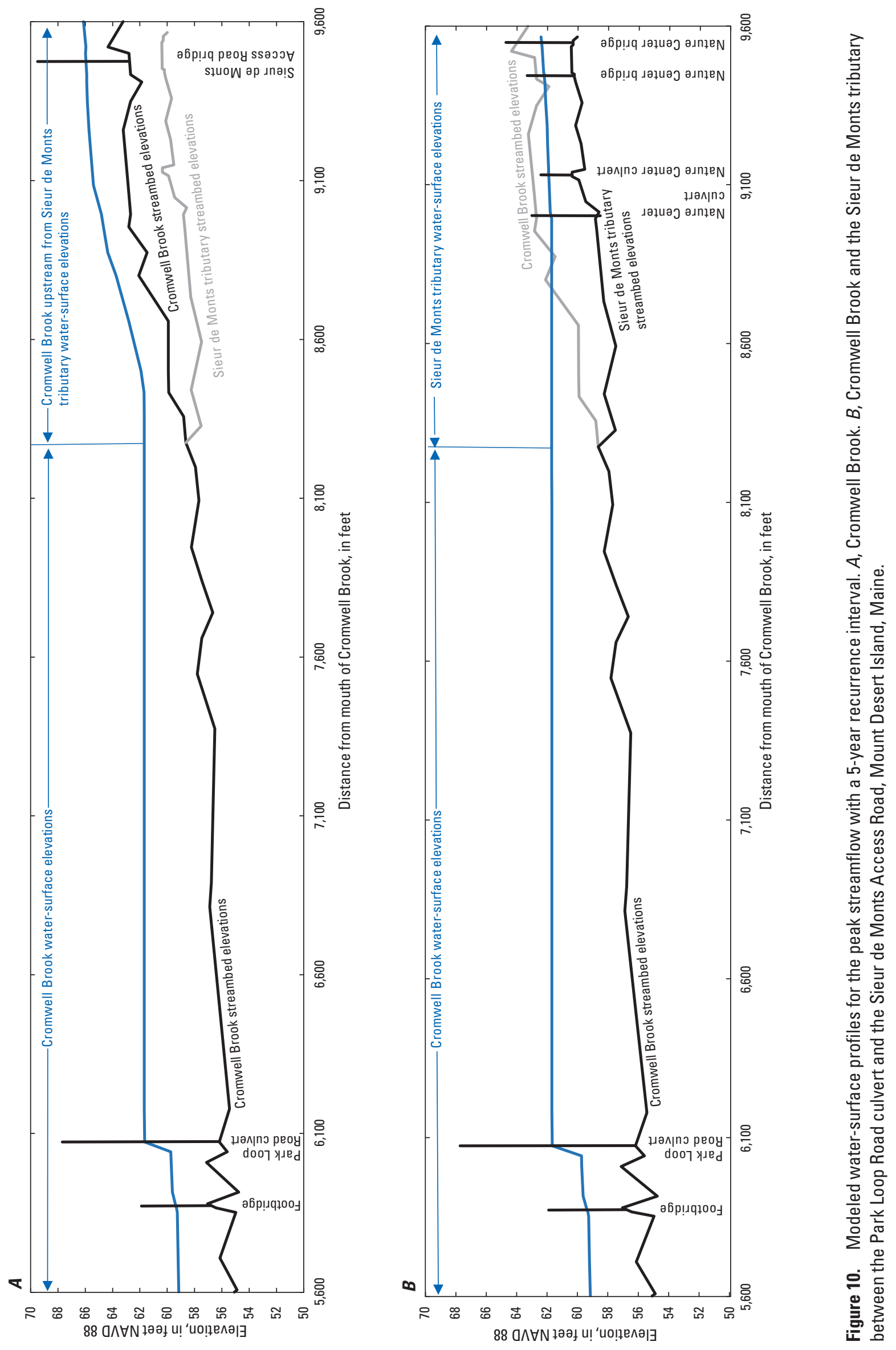

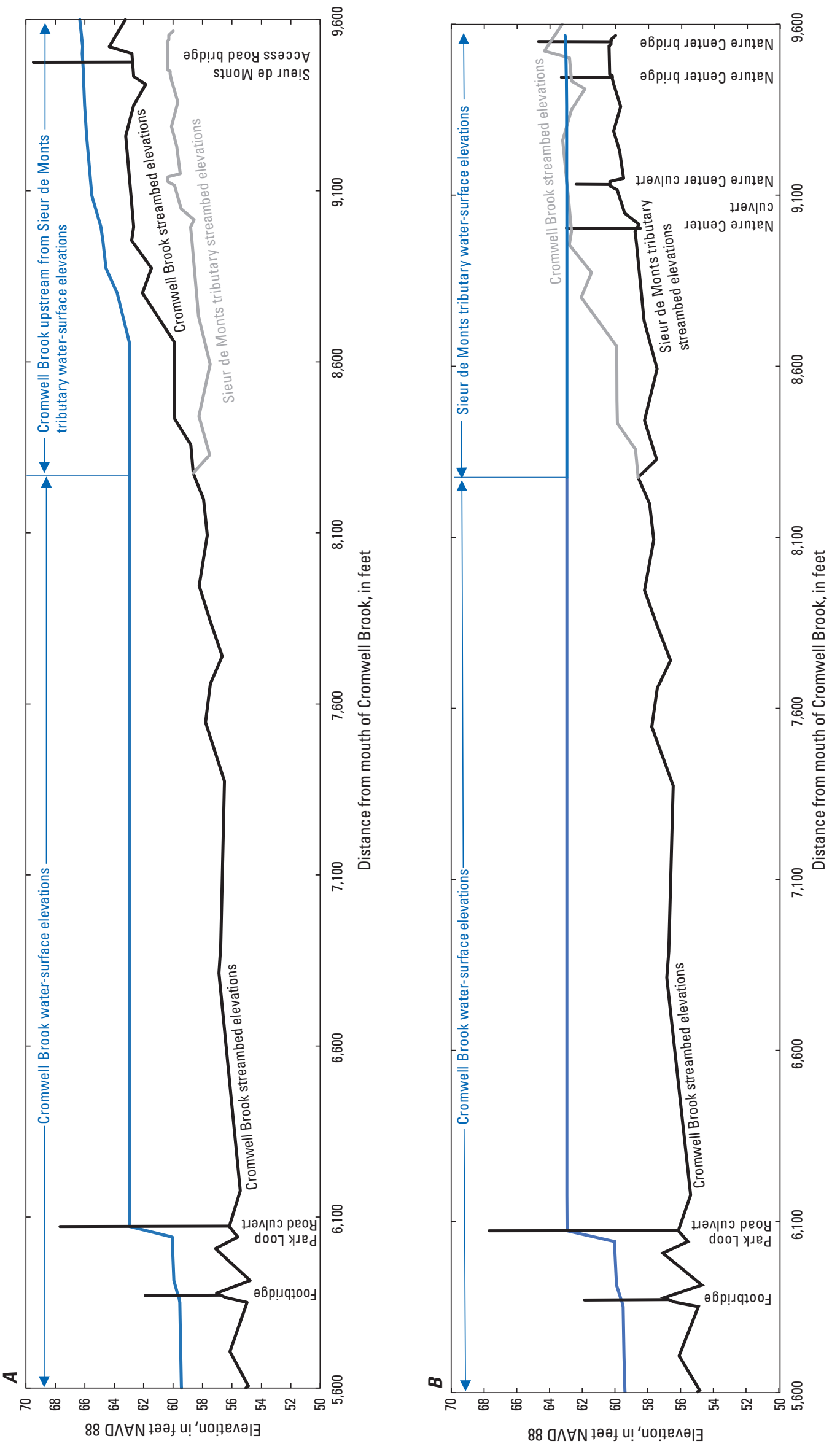

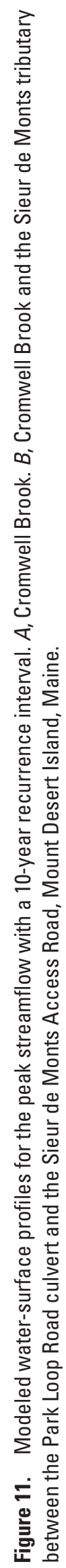



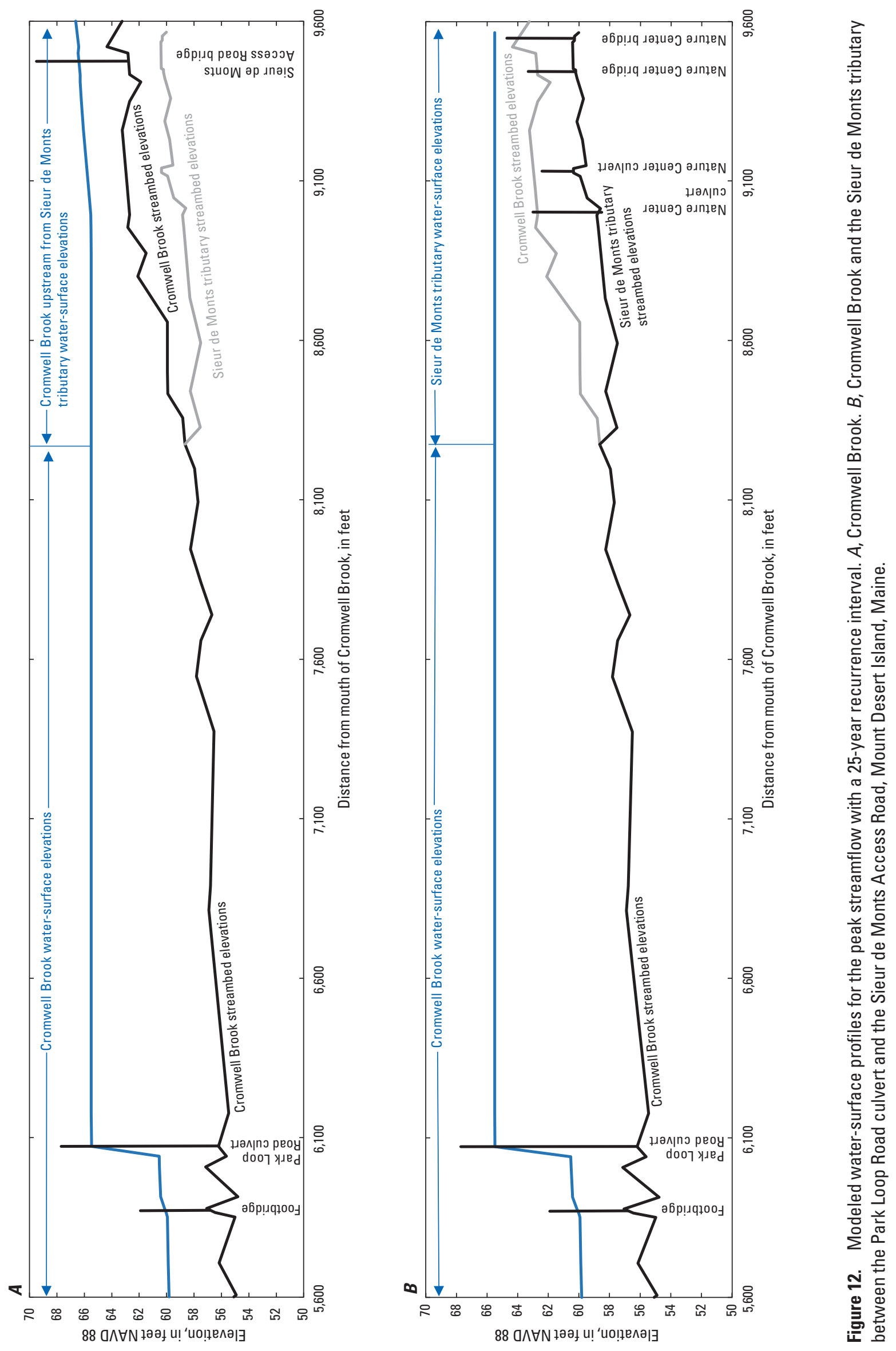

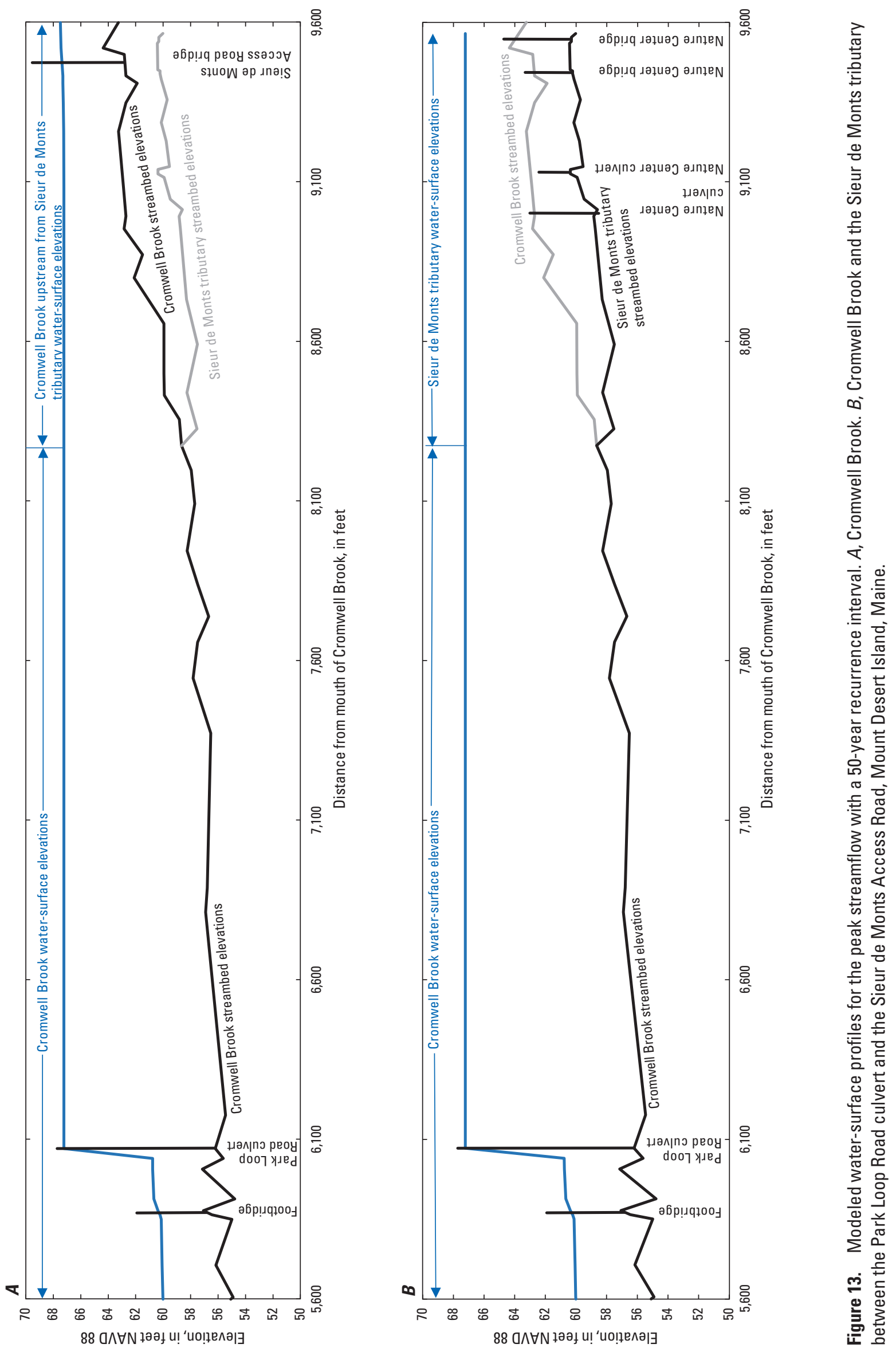

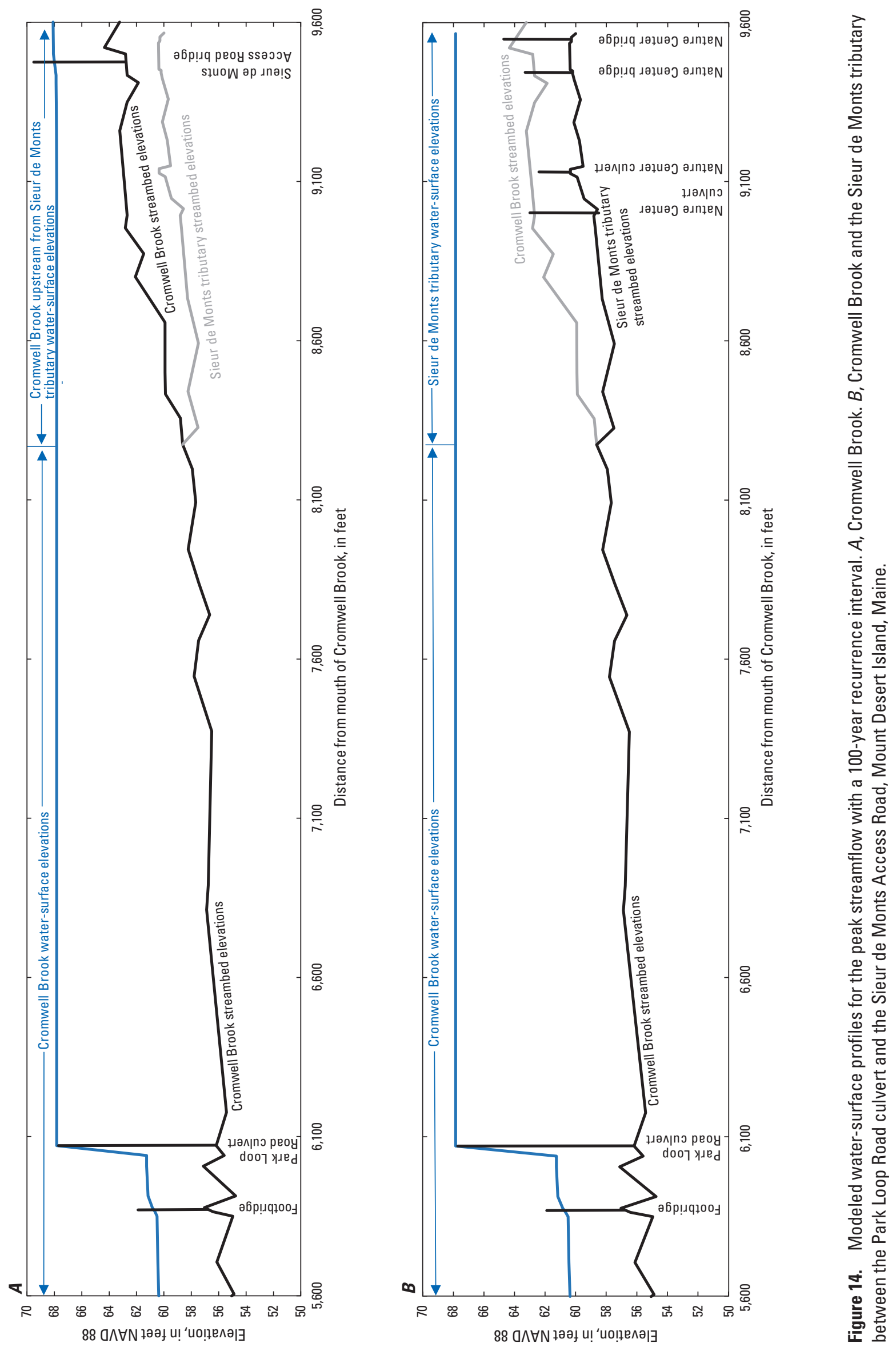
$68^{\circ} 12^{\prime} 45^{\prime \prime}$

$68^{\circ} 12^{\prime} 30^{\prime \prime}$

$68^{\circ} 12^{\prime} 15^{\prime \prime}$

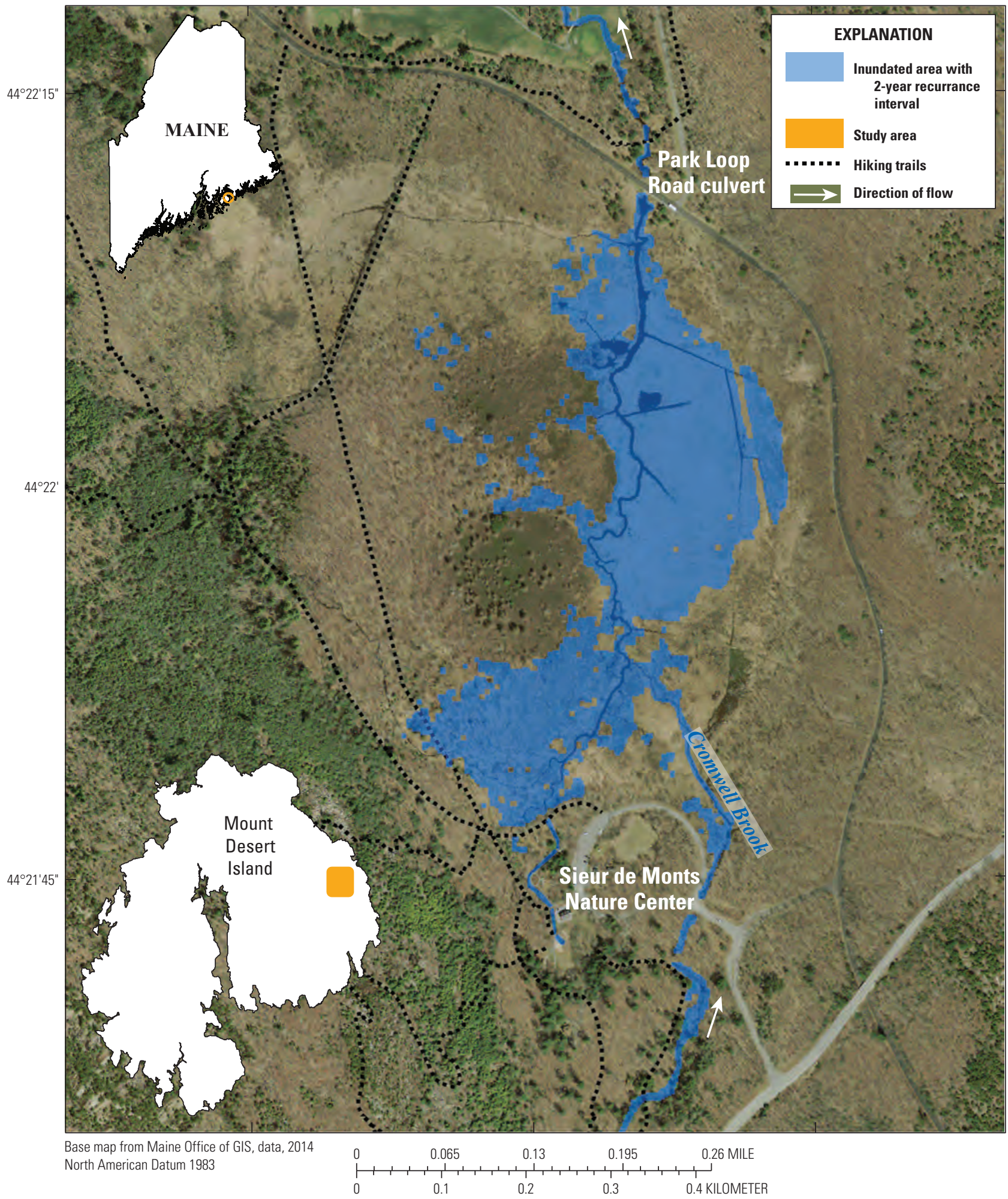

Figure 15. Flood-inundation map for Cromwell Brook at the Great Meadow Wetland for a flow with a 2-year recurrence interval, Mount Desert Island, Maine. 


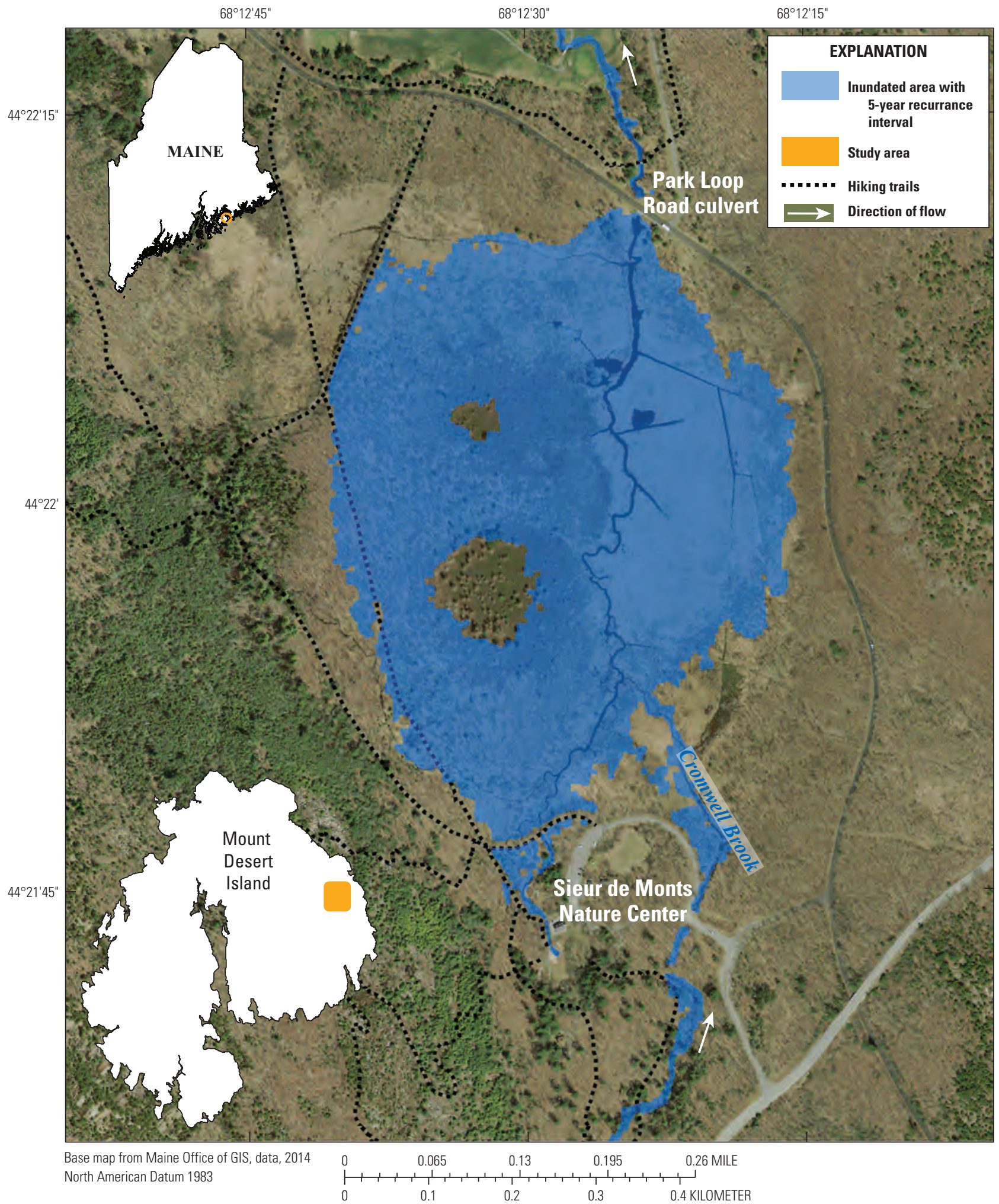

Figure 16. Flood-inundation map for Cromwell Brook at the Great Meadow Wetland for a flow with a 5-year recurrence interval, Mount Desert Island, Maine. 
$68^{\circ} 12^{\prime} 45^{\prime \prime}$

$68^{\circ} 12^{\prime} 30^{\prime \prime}$

$68^{\circ} 12^{\prime} 15^{\prime \prime}$

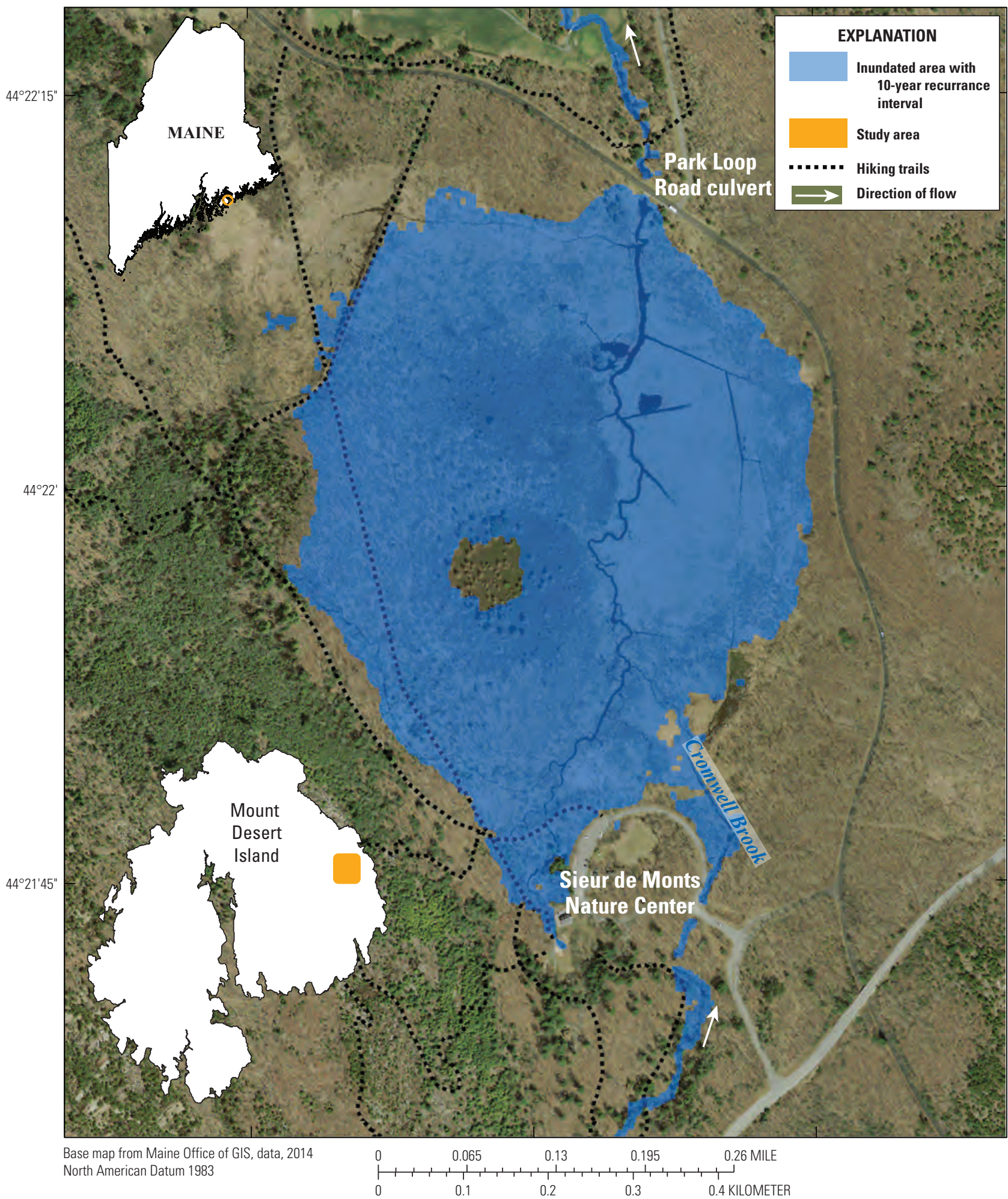

Figure 17. Flood-inundation map for Cromwell Brook at the Great Meadow Wetland for a flow with a 10-year recurrence interval, Mount Desert Island, Maine. 


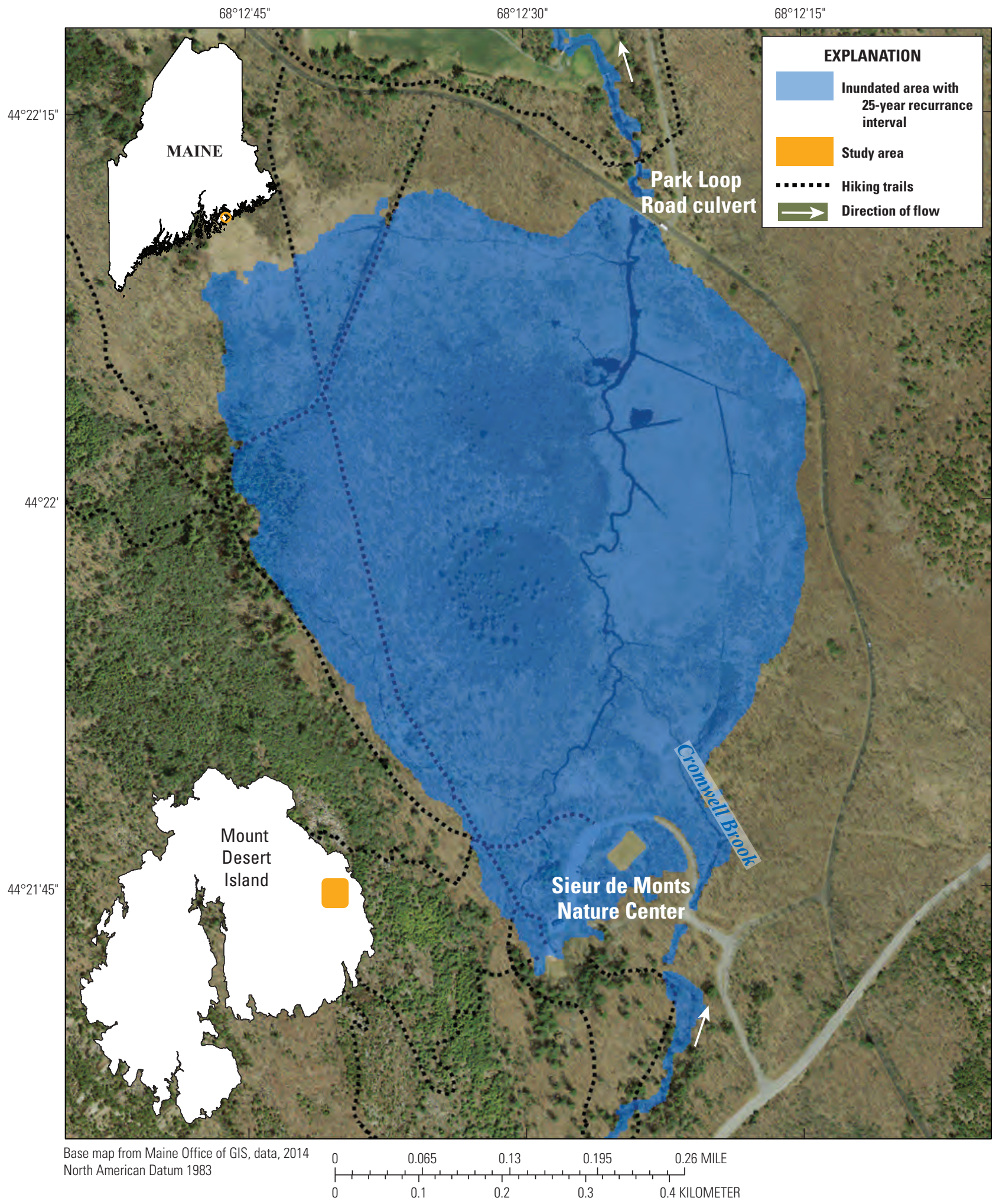

Figure 18. Flood-inundation map for Cromwell Brook at the Great Meadow Wetland for a flow with a 25-year recurrence interval, Mount Desert Island, Maine. 


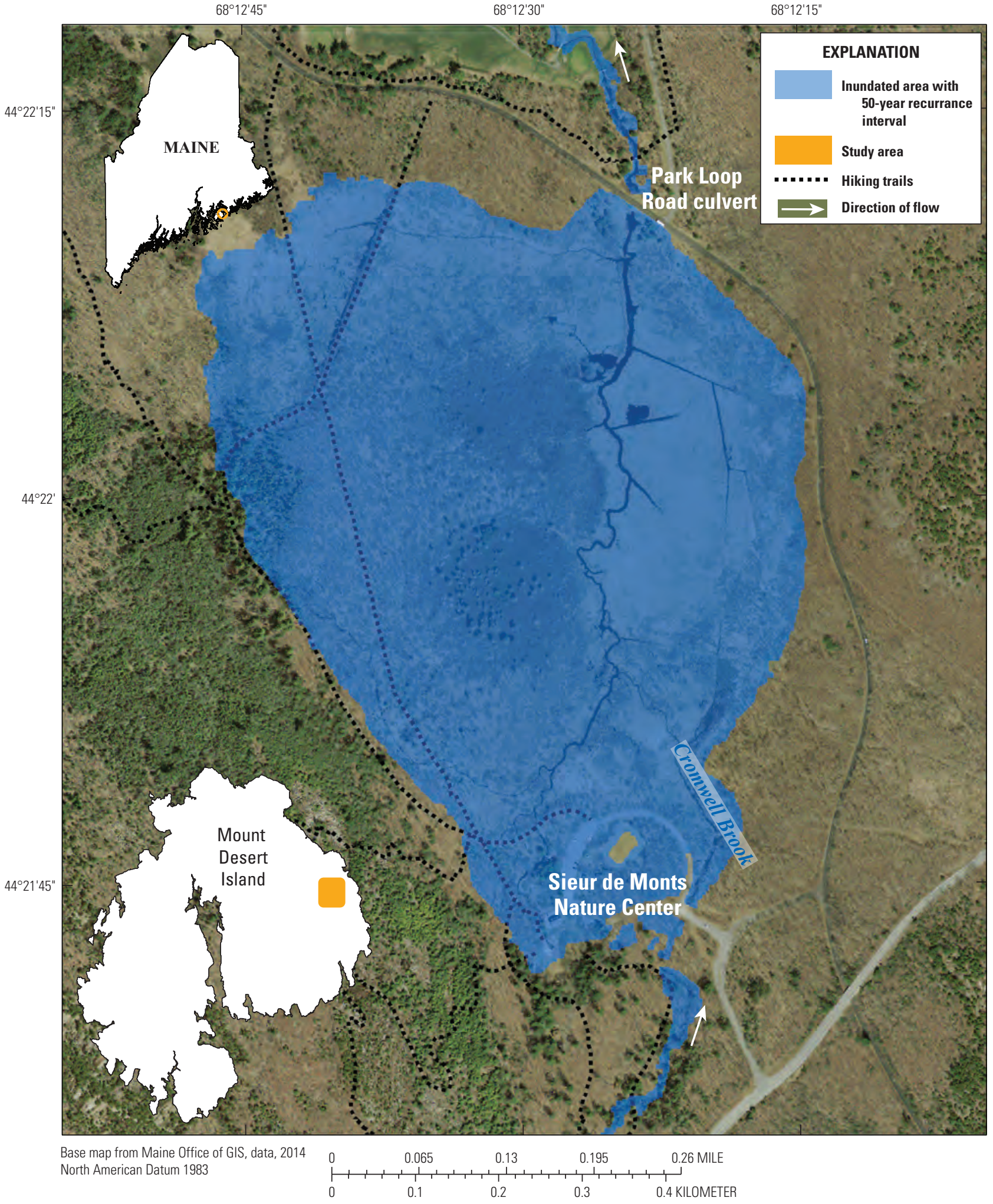

Figure 19. Flood-inundation map for Cromwell Brook at the Great Meadow Wetland for a flow with a 50-year recurrence interval, Mount Desert Island, Maine. 


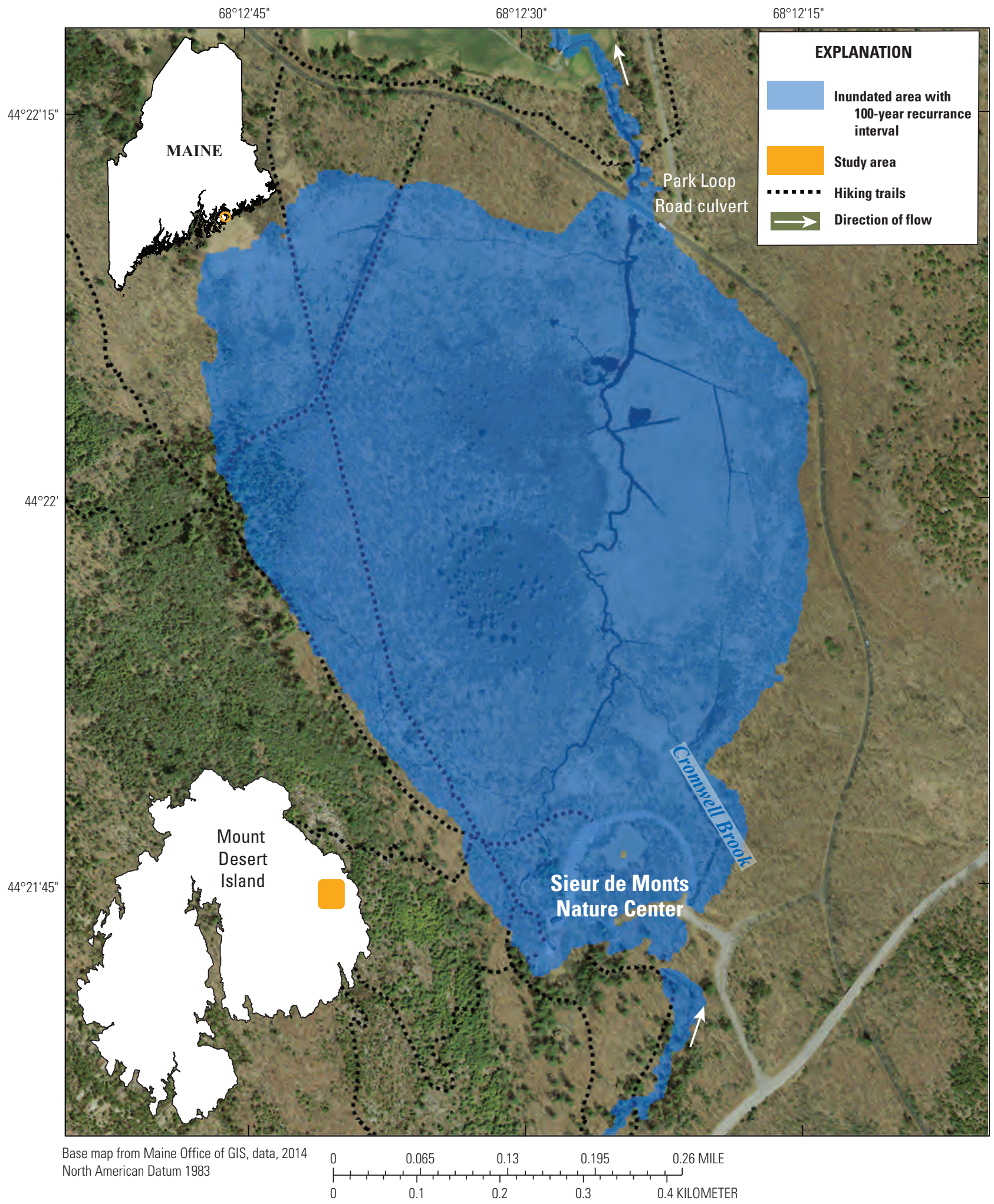

Figure 20. Flood-inundation map for Cromwell Brook at the Great Meadow Wetland for a flow with a 100-year recurrence interval, Mount Desert Island, Maine. 


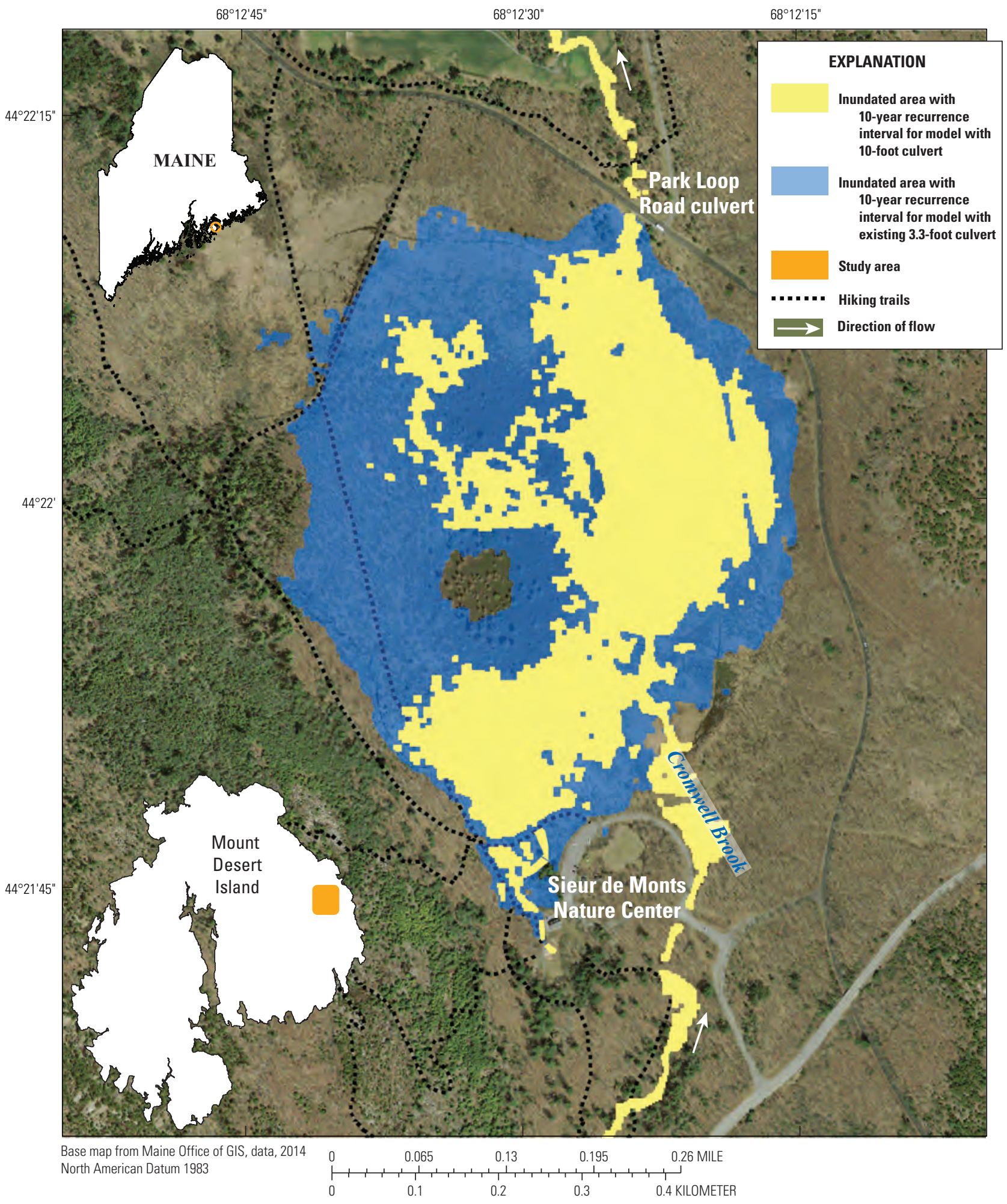

Figure 22. Flood-inundation map for Cromwell Brook at the Great Meadow wetland for the peak streamflow with a 10-year recurrence interval comparing the flooding resulting from a 3.3-ft culvert (blue) versus a 10-ft culvert (yellow) at the Park Loop Road, Mount Desert Island, Maine. 


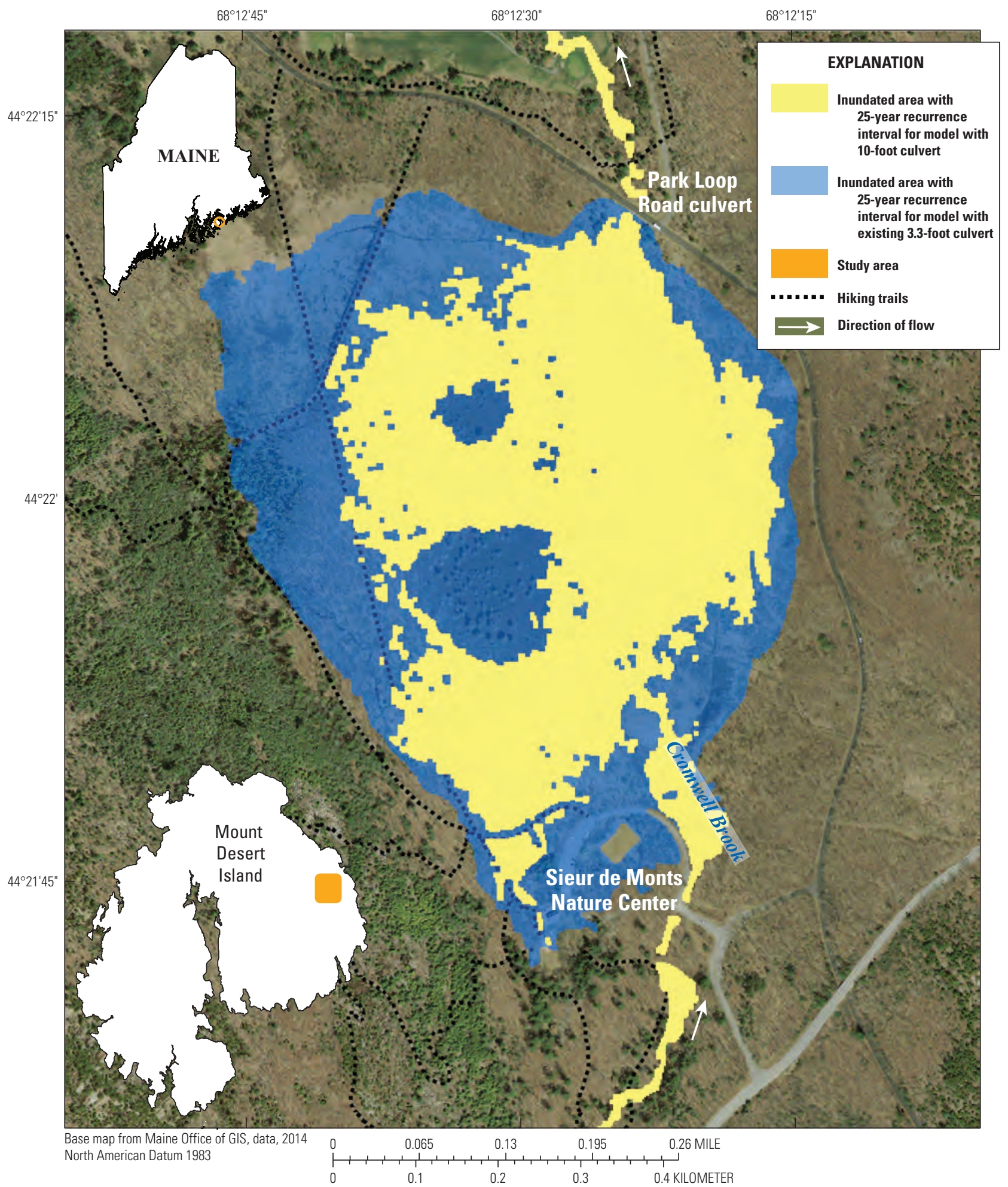

Figure 23. Flood-inundation map for Cromwell Brook at the Great Meadow wetland for the peak streamflow with a 25-year recurrence interval comparing the flooding resulting from a 3.3-ft culvert (blue) versus a 10-ft culvert (yellow) at the Park Loop Road, Mount Desert Island, Maine. 


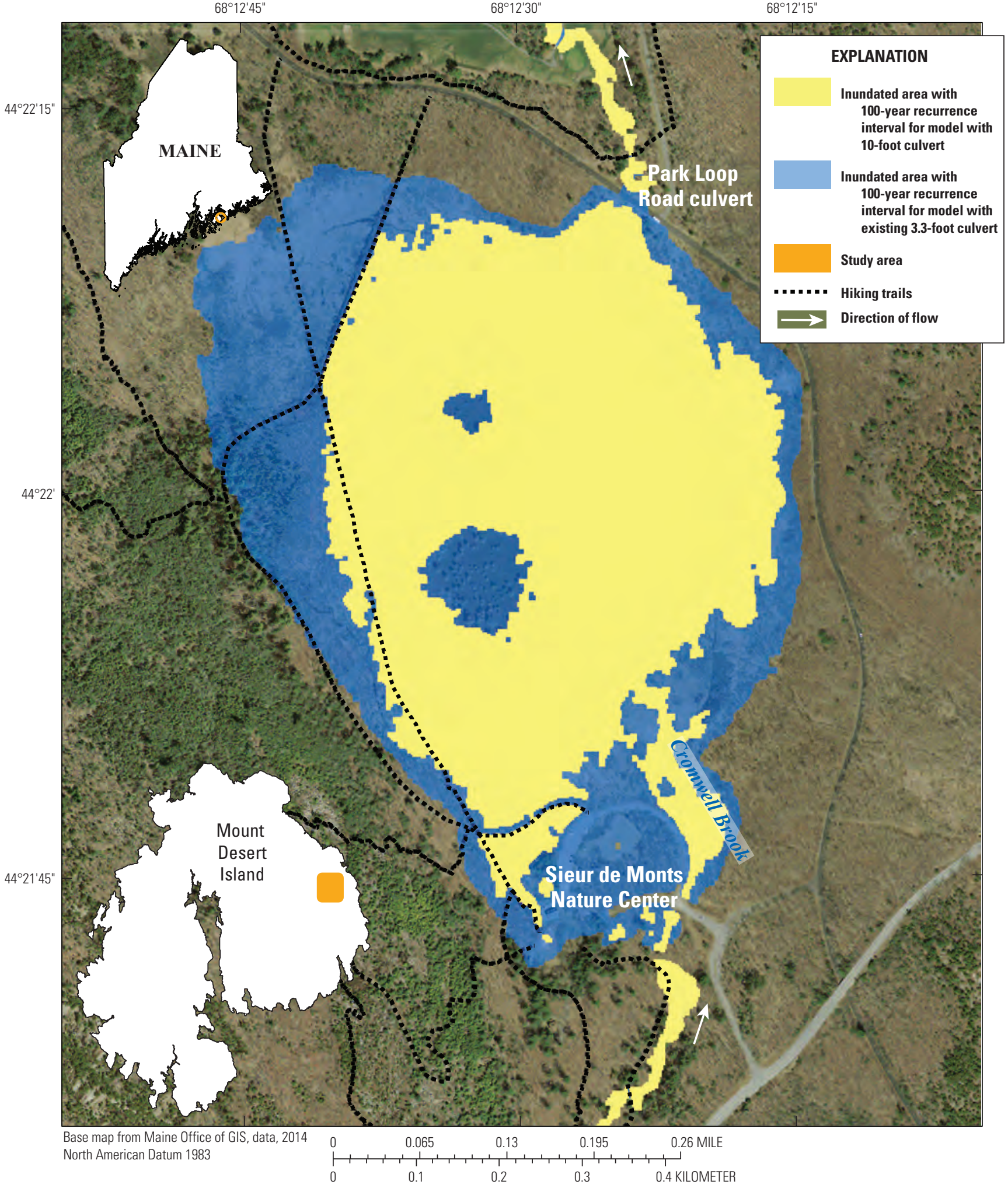

Figure 24. Flood-inundation map for Cromwell Brook at the Great Meadow wetland for the peak streamflow with a 100-year recurrence interval comparing the flooding resulting from a 3.3-ft culvert (blue) versus a 10-ft culvert (yellow) at the Park Loop Road, Mount Desert Island, Maine. 

For more information concerning this report, contact: Director, New England Water Science Center U.S. Geological Survey 196 Whitten Road

Augusta, ME 04330

dc_nweng@usgs.gov or visit our Web site at: http://newengland.water.usgs.gov

Publishing support by:

The Pembroke and Rolla Publishing Service Centers 
蚝 